\title{
Induction of death receptor 5 expression in tumor vasculature by perifosine restores the vascular disruption activity of TRAIL-expressing $\mathrm{CD34}^{+}$cells
}

\author{
Arianna Giacomini - Marco Righi - Loredana Cleris - Silvia L. Locatelli • \\ Stefania Mitola • Maria Grazia Daidone • Alessandro M. Gianni • \\ Carmelo Carlo-Stella
}

Received: 12 October 2012/Accepted: 15 April 2013/Published online: 20 April 2013

(C) Springer Science+Business Media Dordrecht 2013

\begin{abstract}
The proapoptotic death receptor 5 (DR5) expressed by tumor associated endothelial cells (TECs) mediates vascular disrupting effects of human $\mathrm{CD} 34^{+}$cells engineered to express membrane-bound tumor necrosis factor-related apoptosis-inducing ligand (CD34-TRAIL ${ }^{+}$ cells) in mice. Indeed, lack of DR5 on TECs causes resistance to CD34-TRAIL ${ }^{+}$cells. By xenografting in nonobese diabetic/severe combined immunodeficient mice the TRAIL-resistant lymphoma cell line SU-DHL-4V, which generates tumors lacking endothelial DR5 expression, here we demonstrate for the first time that the Akt inhibitor perifosine induces in vivo DR5 expression on TECs, thereby overcoming tumor resistance to the vascular disruption activity of $\mathrm{CD}_{4} 4-\mathrm{TRAIL}^{+}$cells. In fact, $\mathrm{CD}_{4}-\mathrm{TRAIL}^{+}$cells combined with perifosine, but not CD34-TRAIL $^{+}$cells alone, exerted marked antivascular
\end{abstract}

Electronic supplementary material The online version of this article (doi:10.1007/s10456-013-9348-7) contains supplementary material, which is available to authorized users.

A. Giacomini · S. L. Locatelli · C. Carlo-Stella $(\bowtie)$

Department of Oncology and Hematology, Humanitas Cancer Center, Humanitas Clinical and Research Center, Via Manzoni, 56, 20089 Rozzano, Milan, Italy

e-mail: carmelo.carlostella@unimi.it

A. Giacomini - M. Righi - S. L. Locatelli - C. Carlo-Stella Department of Medical Biotechnology and Translational

Medicine, University of Milan, Milan, Italy

\section{Righi}

National Research Council, Institute of Neuroscience, Milan, Italy

L. Cleris · M. G. Daidone

Experimental Oncology, Fondazione IRCCS Istituto Nazionale

Tumori, Milan, Italy effects and caused a threefold increase of hemorrhagic necrosis in SU-DHL-4V tumors. Consistent with lack of DR5 expression, CD34-TRAIL ${ }^{+}$cells failed to affect the growth of SU-DHL-4V tumors, but CD34-TRAIL ${ }^{+}$cells plus perifosine reduced tumor volumes by $60 \%$ compared with controls. In view of future clinical studies using membrane-bound TRAIL, our results highlight a strategy to rescue patients with primary or acquired resistance due to the lack of DR5 expression in tumor vasculature.

Keywords Tumor endothelial cells $\cdot$ Death receptor 5 . Perifosine · TRAIL-expressing CD34 ${ }^{+}$cells · Vascular disruption activity

\section{Introduction}

PI3K/Akt signaling pathway represents an attractive target for anticancer therapy [1-5]. Many new agents targeting this pathway are currently being developed [6]. Perifosine

\footnotetext{
S. Mitola

Department of Molecular and Translational Medicine,

University of Brescia, Brescia, Italy
}

A. M. Gianni $(\bowtie)$

Medical Oncology, Fondazione IRCCS Istituto Nazionale

Tumori, Via Venezian 1, 20133 Milan, Italy

e-mail: alessandro.gianni@unimi.it

A. M. Gianni

Department of Medical Physiopathology and Transplants,

University of Milan, Milan, Italy 
is an oral Akt inhibitor that is being tested in phase I/II clinical trials [7-11]; this drug is a synthetic alkylphospholipid (APL) that targets the pleckstrin homology domain of Akt, thereby preventing its translocation to the plasma membrane [12-15]. Recent reports have shown that the in vitro sensitivity of cancer cell lines to tumor necrosis factor (TNF)-related apoptosis-inducing ligand (TRAIL) can be considerably increased by cotreatment with perifosine due to significant upregulation of death receptors $4 / 5$ (DR4/5) expression as well as downregulation of the antiapoptotic protein cFLIP [16-18].

TRAIL, a proapoptotic member of the TNF superfamily of death receptor ligands, is an attractive cancer cell-specific cytotoxic agent that exerts remarkable antitumor activity in vitro and in vivo in athymic nude mice as well as in non-obese diabetic/severe combined immunodeficient (NOD-SCID) mice [19-29]. The therapeutic activity of recombinant soluble (s)TRAIL and of monoclonal antibodies targeting TRAIL receptors has been extensively explored in phase I/II clinical trials [30-38]. Despite their low toxicity profiles, these molecules have so far shown limited, if any, clinical activity, likely due to the short half-life, the pattern of receptor expression or tumor cell resistance. We have previously demonstrated that adenovirus-transduced CD34 ${ }^{+}$ cells expressing full-length membrane-bound (m)TRAIL $\left(\right.$ CD34-TRAIL $^{+}$cells) efficiently vehiculate TRAIL within tumors and exhibit tumor-specific targeting, overcoming limitations inherent to the pharmacokinetic profile of the soluble molecule [39, 40]. While the intratumor homing of CD34-TRAIL $^{+}$cells involves interactions of SDF-1 and VCAM-1 expressed by tumor endothelial cells with their counter receptors (CXCR4 and VLA-4) expressed by transduced cells, the antitumor activity of mTRAIL requires DR5 expression by tumor vasculature [40, 41]. Engagement of DR5 by CD34-TRAIL ${ }^{+}$cells seems to be a critical step that results in potent vascular disruption activity, which is a distinct property of the membrane-bound TRAIL not shared by its soluble counterpart $[40,41]$. Because vascular targeting appears to be the first step in the complex cascade of events leading to mTRAIL-mediated tumor cell death, lack of DR5 expression in tumor vasculature represents a mechanism of resistance to CD34-TRAIL ${ }^{+}$cells. Thus, modulation of DR5 expression on TECs might not only enhance the antitumor efficacy of CD34-TRAIL ${ }^{+}$cells but also eventually overcome $\mathrm{CD}_{4} 4-\mathrm{TRAIL}^{+}$cells resistance caused by the lack of DR5 expression in tumor vasculature.

Since in vivo modulation of TRAIL receptors on TECs by perifosine has never been reported, we analyzed endothelial DR5 levels in perifosine-treated tumors and investigated the antitumor effects of CD34-TRAIL ${ }^{+}$cells when combined with perifosine. At this aim, two human tumor xenografts growing in NOD/SCID mice were used: the TRAIL-resistant diffuse large B cell lymphoma cell line
SU-DHL-4V, which generates in vivo nodules lacking DR5 expression on TECs, and the TRAIL-sensitive multiple myeloma cell line KMS-11, which generates in vivo nodules expressing DR5 on TECs. Here we demonstrate that perifosine induces expression of DR5 in tumor vasculature and highlight a strategy for overcoming resistance to CD34-TRAIL $^{+}$cells vascular disruption activity. These results appear to be relevant in view of future clinical studies using $\mathrm{CD} 4-\mathrm{TRAIL}^{+}$cells as well as other membrane-bound or cross-linked forms of TRAIL.

\section{Materials and methods}

\section{Reagents}

Perifosine was purchased from Aeterna Zentaris (Frankfurt, Germany, EU); sulfosuccinimidyl-6-(biotinamido) hexanoate (sulfo-NHS-LC-biotin) was purchased from Thermo Fisher Scientific (Rockford, IL, USA) and the specific JNK inhibitor SP600125 was purchased from Calbiochem (Billerica, MA, USA).

\section{Cell lines and CD34 ${ }^{+}$cells}

The tumor-derived endothelial cell line $2 \mathrm{H}-11$ was obtained from the American Type Culture Collection (ATCC, Teddington, UK, EU). The multiple myeloma cell line KMS-11 has been previously described [42]; the diffuse large B cell lymphoma cell line SU-DHL-4 were obtained from the German Collection of Microorganisms and Cell Cultures (DSMZ, Braunschweig, Germany, EU). The SU-DHL-4V cell line was generated in our laboratory after in vivo passaging of the SU-DHL-4 cell line in NOD/SCID mice. SU-DHL-4V cells are TRAIL-resistant and generate in vivo nodules in which TECs lack DR5 expression. KMS-11 cells are TRAIL-sensitive and generate in vivo nodules in which the TECs express DR5. $2 \mathrm{H}-11$ cell line was cultured in DMEM supplemented with $10 \%$ fetal bovine serum (FBS), whereas the SU-DHL-4V and KMS-11 cell lines were cultured in RPMI-1640 supplemented with $10 \%$ FBS. All cell lines were tested for mycoplasma contamination. $\mathrm{CD} 34^{+}$cells were positively selected from the peripheral blood of consenting cancer patients undergoing peripheral blood stem cell mobilization using an AutoMACS device (Miltenyi Biotec, Bergisch-Gladbach, Germany, EU).

Adenoviruses and adenoviral transduction of CD34 ${ }^{+}$ cells

Adenoviral transduction was performed as previously described [39, 43]. 
siRNA gene silencing

2H-11 cells were transfected with $100 \mathrm{nM}$ of either Silencer ${ }^{\circledR}$ Select DR5 small interference RNA (siRNA) or Silencer $^{\circledR}$ Select Negative Control siRNA (Ambion, Carlsbad, CA, USA), according to the instructions of the manufacturer. $24 \mathrm{~h}$ after siRNA transfection, $2 \mathrm{H}-11$ cells were treated with either CD34-TRAIL ${ }^{+}$cells or perifosine $5 \mu \mathrm{M}$ or CD34-TRAIL ${ }^{+}$cells/perifosine in combination. Gene silencing effects were evaluated by western blot and viable cell counting $48 \mathrm{~h}$ after treatments.

Viable cell counting

Annexin-V-fluorescein isothiocyanate/propidium iodide (PI) double staining (Immunostep, Salamanca, SP, EU) was used to detect Annexin- $\mathrm{V}^{-} / \mathrm{PI}^{-}$viable cells by flow cytometry. Absolute cell counts were obtained by the true volumetric absolute counting function of the CyFlow ${ }^{\circledR}$ Space flow cytometer (Partec, Münster, Germany, EU).

In vivo experiments in nonobese diabetic/severe combined immunodeficient (NOD/SCID) mice

Six- to eight-week-old female NOD/SCID mice with body weights of 20-25 g were purchased from Charles River (Milano, Italy, EU). The mice were housed under standard laboratory conditions according to our institutional guidelines. Animal experiments were performed according to the Italian laws (D.L. 116/92 and following additions) that enforce the EU 86/109 Directive and were approved by the institutional Ethical Committee for Animal Experimentation. KMS-11 and SU-DHL-4V cells $\left(5 \times 10^{6}\right.$ cells/ mouse) were inoculated subcutaneously (SC) in the left flank of each mouse. When tumors were palpable, mice were randomly assigned to receive either short- or longterm treatments with either CD34-TRAIL ${ }^{+}$cells, perifosine or CD34-TRAIL ${ }^{+}$cells plus perifosine. Short-term treatments consisted of either a single intravenous (IV) injection of $\mathrm{CD} 4-\mathrm{TRAIL}^{+}$cells $\left(3 \times 10^{6}\right.$ cells/mouse, on day 6 after SU-DHL-4V inoculation and day 12 after KMS-11 inoculation), one 5-days course of oral (PO) perifosine (15 mg/Kg/day, days 5-9 for SU-DHL-4V and days 11-15 for KMS-11), or a combination of both. In vivo biotinylation of tumor vasculature was performed where appropriate $72 \mathrm{~h}$ after the injection of CD34-TRAIL ${ }^{+}$ cells and $3 \mathrm{~h}$ after the last perifosine administration. Tumor nodules were then excised and processed for either histological analysis or ex vivo cytofluorimetric analysis. Longterm treatments consisted of either four daily injections of CD34-TRAIL $^{+}$cells $\left(1 \times 10^{6}\right.$ cells/mouse/day, days 6-9 for SU-DHL-4V and days 12-15 for KMS-11), or two 5-day courses of perifosine $(10 \mathrm{mg} / \mathrm{Kg} /$ day, days 5-9 and
11-15 for SU-DHL-4V; $5 \mathrm{mg} / \mathrm{Kg} /$ day, days $11-15$ and 18-22 for KMS-11), or a combination of both. Control mice received normal saline. The mice were checked twice weekly for the appearance of tumors, tumor dimensions, body weight, and toxicity. The endpoint of the long-term treatment was tumor weight. Tumor volumes were measured with calipers, and their weights were calculated using the formula $\left(a \times b^{2}\right) / 2$, where $a$ and $b$ represented the longest and shortest diameters, respectively. The mice were followed for 2 weeks after the end of the treatments. Each experiment was performed on at least three separate occasions using 5 mice per treatment group. Doses of perifosine were determined as reported in Online resource 1, Fig. S1.

In vivo biotinylation of tumor vasculature

In order to analyze functional tumor vasculature, in vivo biotinylation was performed as previously described [40].

TECs separation from tumor xenografts

SU-DHL-4V and KMS-11 tumor nodules from mice receiving the vehicle control or one 5-days course of perifosine (15 mg/kg/day) were processed for ex vivo cytofluorimetric analysis. Briefly, tumor nodules were excised, immersed in 5-10 $\mathrm{ml}$ of DMEM medium with $10 \%$ FBS (Fetal Bovine Serum) and fragmented with a GentleMacs machine (Miltenyi Biotech) to obtain a cell suspension. When the nodules were completely homogenized, the suspensions were incubated for $45 \mathrm{~min}$ at $37{ }^{\circ} \mathrm{C}$ under constant rotation and in the presence of Collagenase $\mathrm{D}$ (at a final concentration of $2 \mathrm{mg} / \mathrm{ml}$ ) and DNase (at a final concentration of $25 \mu \mathrm{g} / \mathrm{ml}$ ). The cell suspensions were then washed twice at $300 \mathrm{~g}$ for 15 min to inactivate Collagenase D and eliminate platelets and were finally passed through a $30 \mu \mathrm{m}$ filter and labeled with magnetic bead-conjugated anti-mouse CD146 antibody (Miltenyi Biotech) for endothelial cell immunomagnetic sorting by an AutoMACS device (Miltenyi Biotech). Labeling was performed according to the manufacturer's instructions.

Flow cytometric analysis

2H-11 cells co-cultured or not with tumor cells were harvested after $72 \mathrm{~h}$ of exposure to perifosine $5 \mu \mathrm{M}$ and labeled with PE-conjugated anti-DR5 antibody (Biolegend, San Diego, CA, USA). For ex vivo flow cytometric analysis, $\mathrm{CD}_{146^{+}}$subpopulations were collected and labeled with a FITC-conjugated anti-mouse CD146 antibody (Miltenyi Biotech), PE-conjugated anti-mouse DR5 antibody (Biolegend) and 7-AAD to exclude dead cells. Labeling was carried out according to the manufacturer's instructions. 
Samples were analyzed with a FACSCalibur flow cytometry system (BD Biosciences) equipped with a Macintosh PowerMac G4 personal computer (Apple Computer, Cupertino, CA, USA) using CellQuest software (BD Biosciences). The percentages of positive cells were measured according to gates set on the basis of isotype control staining. The intensity of receptor expression was measured as the mean fluorescence intensity (MFI) ratio, which was calculated as the MFI of anti- DR5-stained samples divided by the MFI of isotype control-stained samples.

\section{Western blot analysis}

Cell samples were washed in cold PBS (Phosphate Buffered Saline) and homogenized in NP-40 lysis buffer (1\% NP-40, $20 \mathrm{mM}$ Tris-HCl pH 8, $137 \mathrm{mM} \mathrm{NaCl}, 10 \%$ glycerol, $2 \mathrm{mM}$ EDTA, $1 \mathrm{mM}$ sodium orthovanadate, $10 \mu \mathrm{g} / \mathrm{mL}$ aprotinin, $10 \mu \mathrm{g} / \mathrm{mL}$ leupeptin). Protein concentrations were determined using the Bradford protein assay (Bio-Rad Laboratories, Milano, Italy, EU). Blotting analysis was performed using anti-phospho Akt, anti-total Akt, anti-phospho JNK, anti-total JNK and anti-phospho c-Jun antibodies from Cell Signaling (Danvers, MA, USA), and anti-CD31 and anti-DR5 antibodies from Santa Cruz Biotechnology (Santa Cruz, CA, USA). To normalize the amount of loaded protein, all blots were stripped and reprobed with rabbit polyclonal antibody anti- $-\beta$-actin (GE Healthcare Life Sciences, Milano, Italy, EU).

\section{Reverse transcription-PCR}

Total RNA was isolated with TRIzol reagent (Invitrogen, Carlsbad, CA, USA). Conventional reverse transcriptionPCR and real-time PCR were performed as described previously [39]. The following primers were used to carry out real time PCR:

murine DR5: 5'-TGCTGCTCAAGTGGCGC- $3^{\prime}$ and 5'-GGCATCCAGCAGATGGTTG-3'; murine TBP (internal control): $5^{\prime}$-GGTGTGCACAGGAGCCAAGAGTG- $3^{\prime}$ and $5^{\prime}$-AGCTACTGAACTGCTGGTGGGTC- $3^{\prime}$

\section{Immunofluorescence and confocal microscopy}

Sections ( $4 \mu \mathrm{m}$ thick) of frozen tumors and healthy organs (including lungs, livers and spleens) from in vivo biotinylated mice were fixed with acetone (for $5 \mathrm{~min}$ at $4{ }^{\circ} \mathrm{C}$ ), rinsed with PBS, and blocked with $2 \%$ BSA (Bovine Serum Albumine) in PBS. Sections were then incubated with the appropriate primary antibody (for $1 \mathrm{~h}$ at room temperature), consisting in rabbit anti-human/mouse phospho-Akt (Cell Signaling), rat anti-mouse CD31 (BD Pharmingen) or rabbit anti-mouse CD146 (Novus Biologicals, Littleton, CO, USA). After washing with PBS, sections were incubated with the appropriate Alexa Fluor 488 or 568 -conjugated secondary antibody (Invitrogen). Biotinylated tumor vessels were revealed with Alexa Fluor 488-conjugated streptavidin (Invitrogen). TdT-mediated dUTP nick end labeling (TUNEL) staining (Roche, Milano, Italy, EU) was performed according to the manufacturer's instructions in sections from biotinylated, formalin-fixed, paraffin-embedded tumor nodules, and dead cells were detected in the green channel. TUNEL-stained sections were washed with PBS containing $0.05 \%$ Tween 20, blocked with $2 \%$ BSA (for $10 \mathrm{~min}$ at room temperature) and incubated with Alexa Fluor 568-conjugated streptavidin (Invitrogen) to detect apoptotic tumor vessels or with a rat anti-mouse glycophorin A antibody (BD Pharmingen) followed by the appropriate Alexa Fluor 568-conjugated secondary antibody (Invitrogen) to detect hemorrhagic necrosis areas. Double-stained sections were finally incubated with TO-PRO-3 nuclear dye (Invitrogen). After mounting in a drop of anti-bleaching mounting medium (Vectashield, Vector Laboratories, Burlingame, CA, USA), stained sections were examined under an epifluorescent microscope equipped with a laser confocal system (MRC-1024, Bio-Rad Laboratories, Milano, Italy, EU). Image processing was carried out with LaserSharp computer software (Bio-Rad Laboratories).

\section{Histological analysis and immunohistochemistry}

Formalin-fixed, paraffin-embedded tumor nodules and healthy organs (including lungs, livers, spleens and femurs) were sectioned at a thickness of $2 \mu \mathrm{m}$, dewaxed, hydrated, and stained with hematoxylin and eosin or processed for immunohistochemistry. Tumor cell death was detected using TUNEL staining (Roche) according to the manufacturer's instructions. Cryostat sections ( $4 \mu \mathrm{m}$ thick) of in vivo biotinylated tumor nodules were dried on positively charged glass slides and incubated for $1 \mathrm{~h}$ at room temperature with $1 \mu \mathrm{g} / \mathrm{ml}$ horseradish peroxidase (HRP)-conjugated streptavidin diluted in PBS. Biotinylated tumor endothelia were revealed by $3,3^{\prime}$-diaminobenzidine staining, and tumor sections were then counterstained with Carazzi's hematoxylin, rapidly dehydrated using graded ethanols to xylene and mounted in a drop of fast-drying mounting medium. Sections were examined under a light microscope (BX51; Olympus, Tokyo, Japan) and acquired with an automatic high-resolution scanner (dotSlide System; Olympus). Image processing was carried out using dotSlide software (Olympus).

Analysis of stained sections

Image analysis was performed using the open source ImageJ software (http://rsb.info.nih.gov/ij/). Routines for 
image analysis were coded in Image J macro language and executed on RGB images without further treatment. For each experimental condition, at least three sections from different tumor nodules were analyzed. Analysis to calculate the endothelial area (i.e., the percentage of the tissue section occupied by endothelium) and the percent of tumor necrosis expressed as (necrotic area)/(total tissue area) $\times 100$ were performed as previously described [40]

\section{Statistical analyses}

Statistical analyses were performed using the statistical package Prism 5 (GraphPad Software) run on a Macintosh Pro personal computer (Apple Computers). Student's $t$ test for unpaired data (2-tailed) was used to test the probability of significant differences between untreated and treated samples. TUNEL staining and tumor vasculature data were statistically analyzed with a 1-way analysis of variance, and individual group comparisons were evaluated by the Bonferroni multiple comparison test. Tumor volume data were statistically analyzed with a 2-way analysis of variance, and individual group comparisons were evaluated by the Bonferroni correction. Differences were considered significant if $P$ was $\leq 0.05$.

\section{Results}

Perifosine inhibits Akt phosphorylation and increases DR5 expression in tumor-derived endothelial cells in vitro

In order to investigate the effects of perifosine on TECs, we first performed in vitro experiments using the $2 \mathrm{H}-11$ tumor endothelial cell line [44]. 2H-11 cells were exposed to perifosine $5 \mu \mathrm{M}$ for $72 \mathrm{~h}$ and analyzed for phospho Akt and DR5 expression. As assessed by immunofluorescence and western blot analysis, perifosine caused a strong decrease in Akt phosphorylation levels without affecting total Akt expression (Fig. 1a, c). Interestingly, reduced levels of activated Akt were paralleled by a significant increase in DR5 expression as shown by flow cytometric $(64.8 \pm 1.4$ vs. $83.0 \pm 1.2 \%$, mean $\pm \mathrm{SD} ; * P<0.01)$ and western blot analysis (Fig. 1b, c). Considering that it has been reported the c-Jun NH2-terminal kinase-dependent upregulation of DR5 by perifosine in leukemia cells [17] and head and neck squamous cell carcinomas [18], we examined the possibility that perifosine upmodulates DR5 levels via JNK also in tumor-derived endothelial cells. Thus, we investigated by western blot analysis the modulation of JNK and c-Jun activation in $2 \mathrm{H}-11$ cells following treatment with perifosine. As shown in Fig. 1c, perifosine increased the phosphorylation levels of both JNK and
c-Jun. Interestingly, inhibition of JNK by the specific inhibitor SP600125 prevented DR5 perifosine-induced upregulation (Fig. 1c), supporting the hypothesis that perifosine upmodulates DR5 levels via JNK activation.

DR5 expression on TEC is needed for CD34-TRAIL ${ }^{+}$ cells antivascular activity

In order to investigate whether the DR5 expression on tumor endothelial cells is required for CD34-TRAIL ${ }^{+}$cells antivascular activity, we silenced the expression of DR5 in $2 \mathrm{H}-$ 11 cells using small interfering RNA (siRNA) and then examined cell sensitivity to CD34- $\mathrm{TRAIL}^{+}$cells alone or in combination with perifosine. As shown in Fig. 1d, 2H-11 cell viability accounted for $59.5 \pm 10.2 \%$ (mean \pm SD) of controls following treatment with CD34-TRAIL ${ }^{+}$cells and addition of perifosine caused a $28 \%$ further reduction in cell viability compared with $\mathrm{CD}_{4} 4-\mathrm{TRAIL}^{+}$cells alone $(42.8 \pm 10.8$ vs. $59.5 \pm 10.2 \%$, mean $\pm \mathrm{SD}, P<0.05)$, whereas perifosine alone was not able to significantly affect $2 \mathrm{H}-11$ cell viability. By western blotting, we detected substantially reduced levels of DR5 in both perifosine-treated and perifosine-untreated $2 \mathrm{H}-11$ cells transfected with DR5 siRNA compared with control siRNA-transfected cells (Fig. 1d). Interestingly, silencing of DR5 expression prevented CD34-TRAIL ${ }^{+}$cells-induced $2 \mathrm{H}-11$ cell death. In fact, a significant increase in cell viability was observed in DR5 siRNA-transfected cells after treatment with both CD34-TRAIL ${ }^{+}$cells alone and in combination with perifosine compared to control siRNA-transfected cells $(91.7 \pm 8.9$ vs. $59.5 \pm 10.2 \%$, mean $\pm \mathrm{SD}, P<0.01$, and $89.0 \pm 11.3$ vs. $42.8 \pm 10.8 \%$, mean $\pm \mathrm{SD}, P<0.01$, respectively). These findings suggest that DR5 expression is required for $\mathrm{CD}_{34-\mathrm{TRAIL}^{+}}$cells-induced tumor endothelial cell death and confirm that DR5 up-regulation is the mechanism involved in perifosine-enhancement of CD34-TRAIL ${ }^{+}$cells antivascular activity.

Perifosine inhibits in vivo Akt phosphorylation both in tumor cells and tumor vasculature

To determine whether treatment with perifosine modulated Akt phosphorylation in vivo, tissue sections from control and perifosine-treated tumors were analyzed by confocal microscopy. Both SU-DHL-4V and KMS-11 tumor cells showed high levels of phosphorylated Akt (Fig. 2) and, in both instances, perifosine markedly decreased Akt phosphorylation (Fig. 2). Interestingly, in keeping with in vitro observations, in vivo biotinylated endothelial cells (see "Materials and methods" section) of both SU-DHL-4V and KMS-11 tumors also showed intense expression of phosphorylated Akt, which was strongly inhibited by perifosine (Fig. 2, magnified fields). In order to better evaluate in vivo 

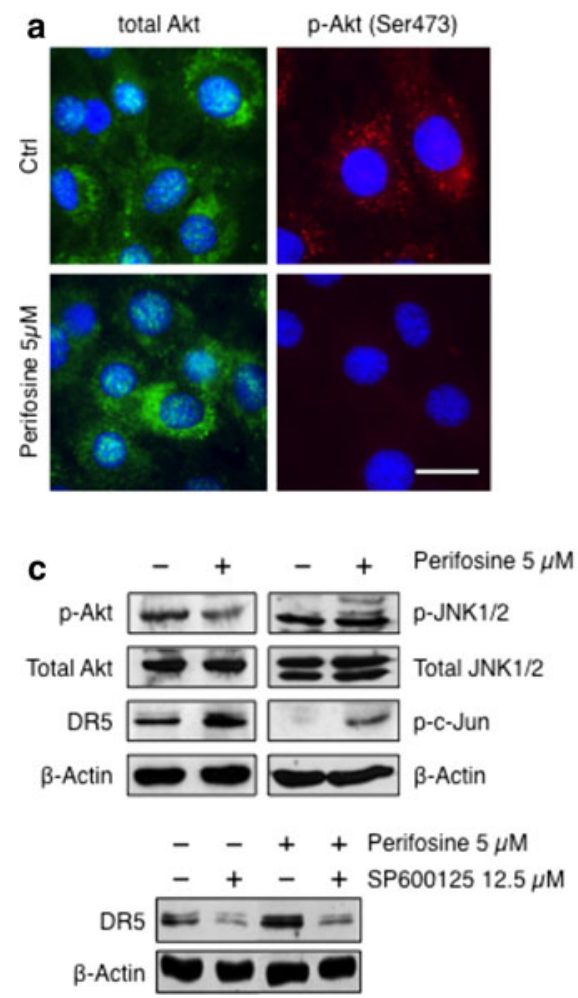

Fig. 1 Perifosine effects on tumor-derived endothelial cells in vitro. a-c $2 \mathrm{H}-11$ cells were exposed to perifosine $5 \mu \mathrm{M}$ for $72 \mathrm{~h}$. a Immunofluorescence staining for total and phosphorylated Akt (scale bar $30 \mu \mathrm{m})$. b DR5 expression by cytofluorimetric analysis. Representative mean fluorescence intensity (MFI) histograms and values for mean $( \pm \mathrm{SD})$ percentage of positive cells are shown $(* P<0.01$ compared with control). Percentages of positive cells were measured according to gates set on the basis of isotype control staining (grey filled histograms). c Western blot analysis of DR5 expression and Akt, JNK and c-Jun activation following perifosine treatment. To investigate the role of JNK in perifosine-induced DR5 expression in tumor endothelial cells, $2 \mathrm{H}-11$ cells were treated with the specific

perifosine effects on TECs, tumor nodules from mice receiving control vehicle or perifosine were collected and homogenized to obtain a cell suspension. As CD146 is widely expressed by murine endothelial cells $[45,46]$ and by the endothelium of both SU-DHL-4V and KMS-11 tumor models (Fig. 3a), TECs were efficiently separated from tumor cells by immunomagnetic sorting using a magnetic bead-conjugated anti-mouse CD146 antibody (Fig. 3b). Western blot analysis of CD146 ${ }^{+}$and CD146 subpopulations from SU-DHL-4V tumors confirmed in vivo phospho Akt modulation by perifosine in both tumor cells and TECs (Fig. 3c). To rule out a potential cause of systemic toxicity, Akt phosphorylation was also investigated in normal tissues. No activation of Akt was observed in the lungs or the lung endothelium (Online resource 1, Fig. S2), whereas the liver parenchyma, but not liver endothelial cells, showed weak expression of phosphorylated Akt, which was not influenced by perifosine
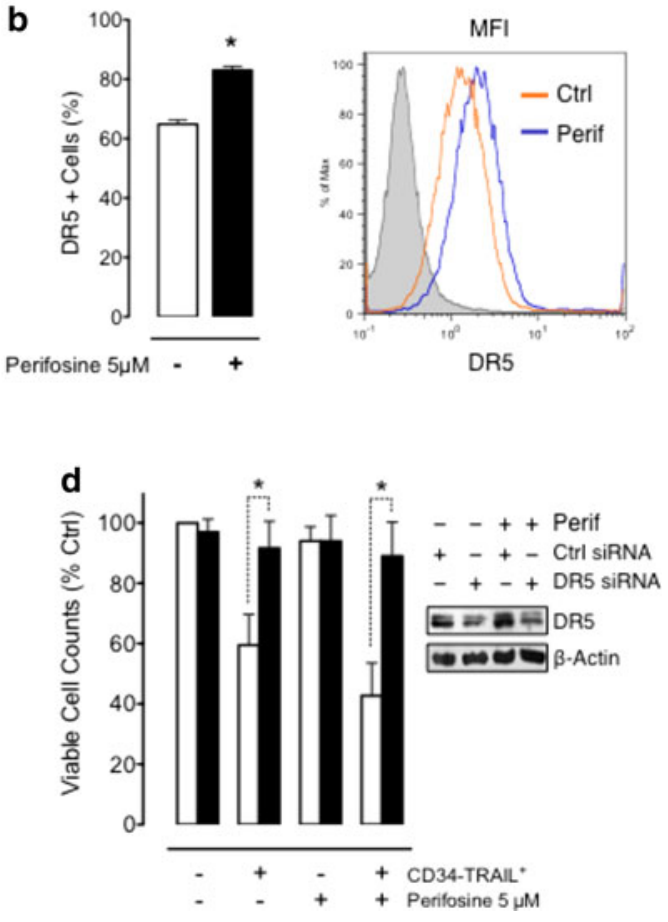

JNK inhibitor SP600125 for $1 \mathrm{~h}$ before treatment with perifosine. d $2 \mathrm{H}-11$ cells were transfected with $100 \mathrm{nM}$ of either DR5 siRNA (black bars) or negative control siRNA (white bars). $24 \mathrm{~h}$ after siRNA transfection, $2 \mathrm{H}-11$ cells were treated with either CD34-TRAIL ${ }^{+}$ cells or perifosine $5 \mu \mathrm{M}$ or $\mathrm{CD} 34-\mathrm{TRAIL}^{+}$cells/perifosine in combination. Viable cell countings were performed $48 \mathrm{~h}$ after treatments as described in the "Materials and methods" section. The mean \pm SD percentages are shown. $* P<0.01$. Gene silencing effects on DR5 expression in perifosine-treated and perifosineuntreated cells transfected with $100 \mathrm{nM}$ of either DR5 siRNA or negative control siRNA were evaluated by western blot analysis

treatment. The spleen endothelium failed to express phospho-Akt, which was however expressed by the parenchyma, but also in this case the level of Akt phosphorylation was not modulated by treatment with perifosine (Online resource 1, Fig. S2).

\section{Perifosine induces in vivo DR5 expression on TECs}

Ex vivo cytofluorimetric analysis of $\mathrm{CD} 146^{+}$subpopulations revealed a significant increase of DR5 positive TECs derived from perifosine-treated tumors. Interestingly, TECs from control SU-DHL-4V tumors did not express DR5 ( $4 \pm 4 \%$, mean $\pm \mathrm{SD}$ ), whereas perifosine-treated tumors showed an average of $42 \pm 6 \%$ DR5-positive endothelial cells $(P<0.05)$, with an average 3.6 -fold increase of the mean fluorescence intensity being observed compared to controls (Fig. 4a), suggesting perifosine was able to induce de novo expression of DR5 in TECs. Up-regulation of DR5 

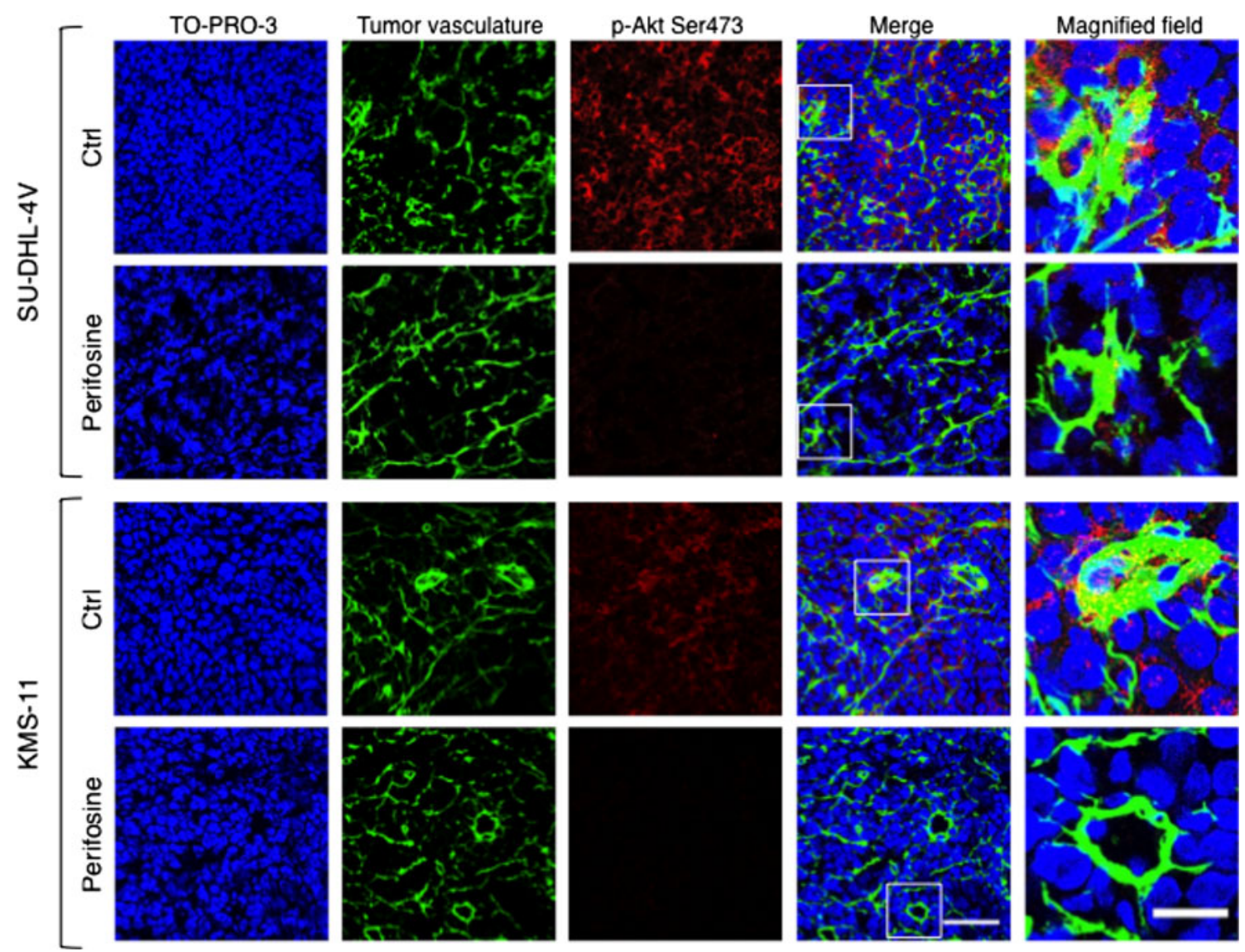

Fig. 2 In vivo perifosine-induced inhibition of Akt phosphorylation in tumor cells and tumor vasculature. NOD/SCID mice bearing subcutaneous tumor nodules received perifosine at $15 \mathrm{mg} / \mathrm{kg}$ (once daily for 5 days, PO), or the vehicle control. Immediately prior to sacrifice, NOD/SCID mice were IV injected with $0.2 \mathrm{ml}$ of sulfoNHS-LC-biotin $(5 \mathrm{mg} / \mathrm{ml})$ to biotinylate the tumor vasculature. Tumor nodules were then harvested, freshly snap-frozen in isopentane and analyzed for phospho-Akt expression. Representative confocal images of tumors from vehicle control-treated and perifosine-treated mice are shown. Cryosections were processed by triple immunofluorescence staining to detect tumor and endothelial phospho-Akt expression. Cell nuclei were detected by blue coloration with TO-PRO-3 staining; biotinylated tumor vasculature were detected

on TECs enriched from perifosine-treated SU-DHL-4V tumors was also observed by RT-PCR (Online resource 1, Fig. S3), indicating that perifosine modulated DR5 at mRNA level. Also TECs from perifosine-treated KMS-11 tumors showed a significant increase in the percentages of DR5-expressing cells $(81 \pm 8$ vs. $42 \pm 8 \%, P<0.05)$ and a threefold increase of the mean fluorescence intensity compared to controls (Fig. 4a). Increased levels of DR5 were confirmed also by western blot analysis performed with proteins obtained from $\mathrm{CD}_{146^{+}}$subpopulations (Fig. 4b). To investigate if also in vivo perifosine-induced DR5 upregulation on TECs was paralleled by JNK pathway activation, phospho-JNK and phospho-c-Jun levels were assessed by western blot analysis. Interestingly, as by green staining with Alexa 488-conjugated streptavidin; and phosphorylated Akt was detected by red coloration incubating sections with an anti-human/mouse phospho-Akt antibody followed by the appropriate Alexa Fluor 568-conjugated secondary antibody. After merging of the single color images, tumor cells expressing phospho-Akt were red, whereas endothelial cells expressing phosphoAkt resulted in yellow coloration due to colocalization with sulfobiotin staining, as shown in the magnified fields. White squares indicate the image field magnified. Objective lens, original magnification: $1.0 \mathrm{NA}$ oil objective, $\times 40$; scale bar $50 \mu \mathrm{m}$. Magnified fields, objective lens, original magnification: 1.4 NA oil objective, $\times 60$; scale bar $10 \mu \mathrm{m}$. (Color figure online)

observed in vitro with $2 \mathrm{H}-11$ cells, in vivo treatment with perifosine increased the phosphorylation levels of JNK and c-Jun in the endothelial cells of both tumor models (Fig. 4b).

Baseline expression of DR5 in the endothelial cells enriched from SU-DHL-4V and KMS-11 tumors was substantially different, notwithstanding they derived from the same host normal endothelium. This suggests TECs phenotype was tightly dependent on tumor type. In order to better understand this phenomenon, we co-cultured in vitro for $72 \mathrm{~h} 2 \mathrm{H}-11$ cells with either SU-DHL-4V or KMS-11 cells and analyzed DR5 expression on 2H-11 cells by flow cytometry. Interestingly, KMS-11 cells did not affect DR5 expression on $2 \mathrm{H}-11$ cells, whereas SU-DHL4V cells 
Fig. 3 Efficient separation of TECs from subcutaneous tumors. SU-DHL-4V and KMS-11 tumor nodules from mice receiving the vehicle control or perifosine at $15 \mathrm{mg} / \mathrm{kg}$ (once daily for 5 days, PO) were collected and homogenized to obtain a cell suspension. TECs were efficiently separated from tumor cells by immunomagnetic sorting using a magnetic beadconjugated anti-mouse CD146 antibody. a Cryosections from both tumor models double stained for CD31 and CD146 antigens demonstrating expression of CD146 by tumor associated endothelial cells. Scale bars $50 \mu \mathrm{m}$. b, c Western blot analysis of CD146 ${ }^{+}$and CD146- subpopulations from SU-DHL-4V tumors for CD31 (b) and phospho and total Akt expression (c)

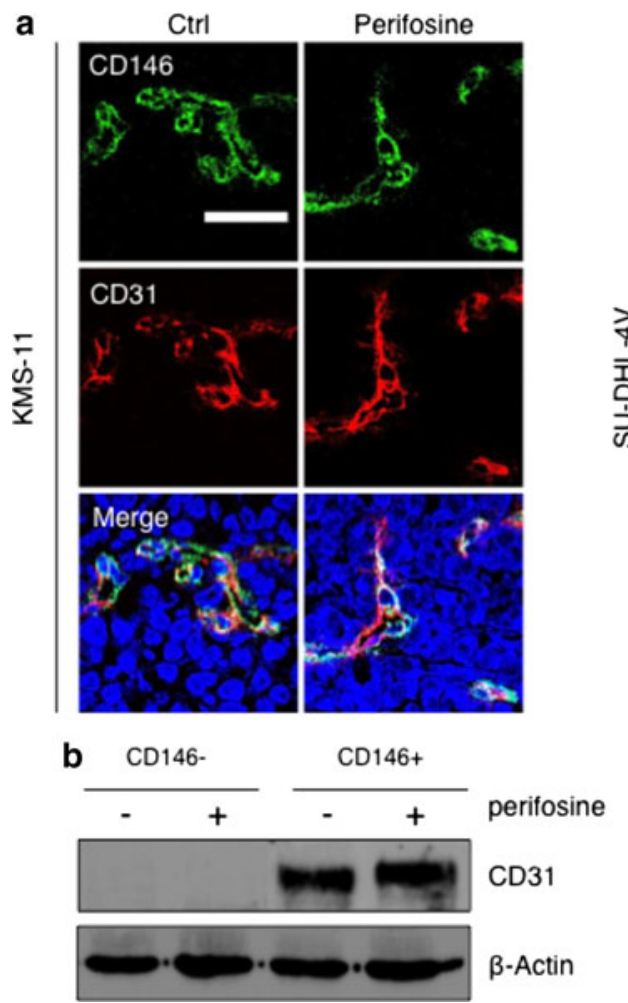

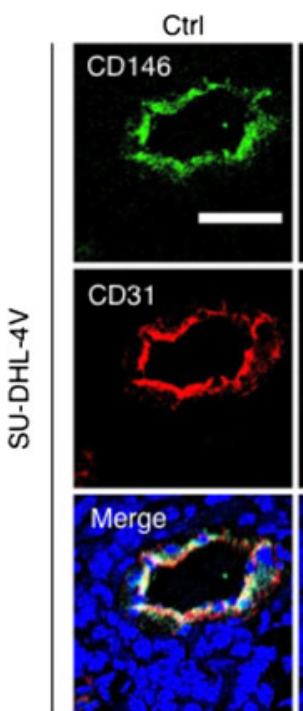
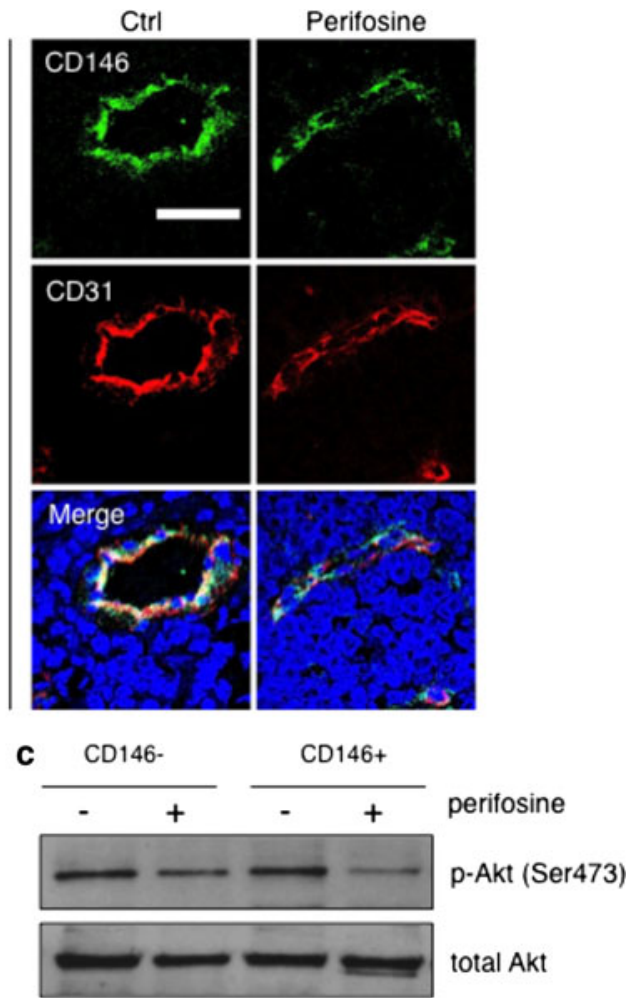
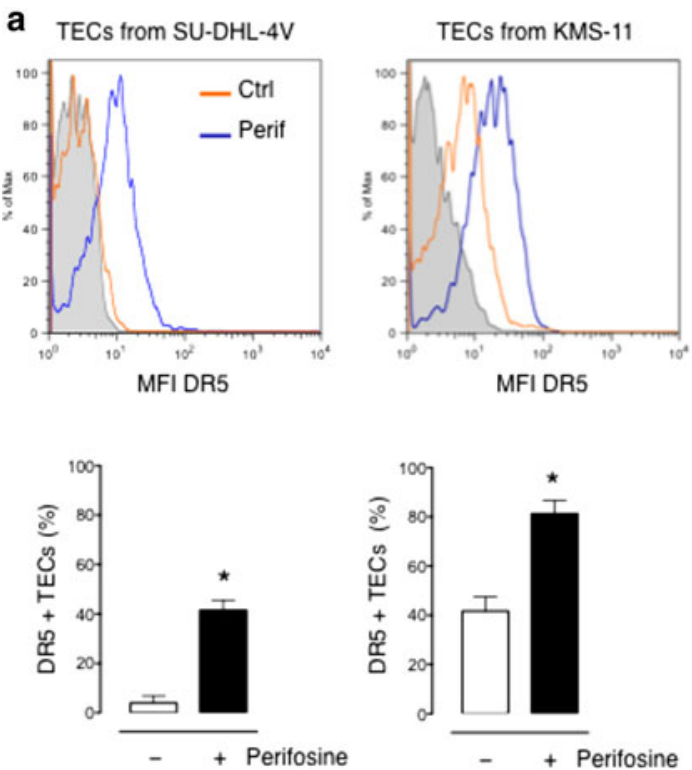

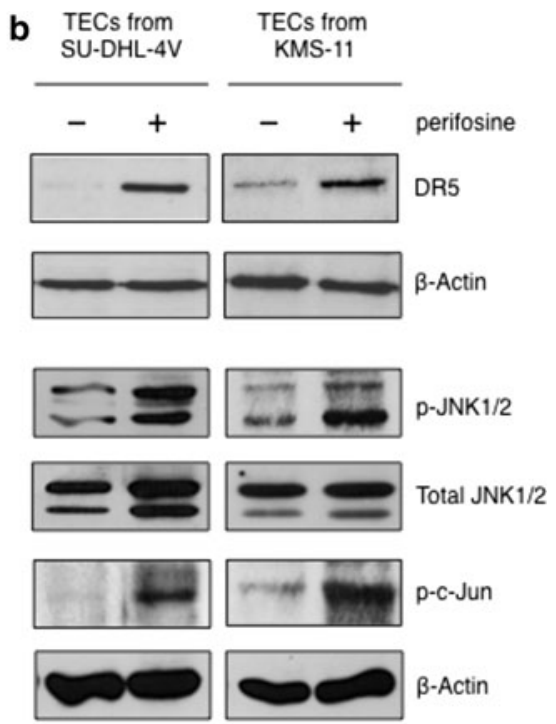

Fig. 4 In vivo DR5 modulation on TECs by perifosine. CD146 ${ }^{+}$ subpopulations from SU-DHL-4V and KMS-11 tumor nodules from mice receiving the vehicle control or perifosine at $15 \mathrm{mg} / \mathrm{kg}$ (once daily for 5 days, PO) were processed for a cytofluorimetric analysis to evaluate DR5 expression and $\mathbf{b}$ western blot analysis to evaluate DR5 levels and JNK and c-Jun activation. a Representative mean

caused a $29 \%$ reduction of DR5 expressing cells $(64.8 \pm 1.4$ vs. $46.3 \pm 1.6 \%$ ) (Online resource 1, Fig. S4). Surprisingly, addition of perifosine to $2 \mathrm{H}-11 / \mathrm{SU}-$ DHL-4V co-cultures restored basal DR5 levels in $2 \mathrm{H}-11$ fluorescence intensity (MFI) histograms and data regarding the mean \pm SD percentage of positive cells are shown. The percentages of positive cells were measured according to gates set on the basis of isotype control staining (grey filled histograms). ${ }^{*} P<0.05$ compared with controls

cells (Online resource 1, Fig. S4). Addition of SU-DHL-4V conditioned medium to $2 \mathrm{H}-11$ cultures did not affect DR5 expression, suggesting cell contact was necessary (data not shown). 
Perifosine triggers the vascular disruption activity of CD34-TRAIL ${ }^{+}$cells in SU-DHL-4V tumors lacking vascular DR5

Expression of DR5 on TECs is a pre-requisite for the vascular disruption activity of $\mathrm{CD} 4-\mathrm{TRAIL}^{+}$cells [40, 41]. To investigate the impact of perifosine-induced DR5 modulation on the vascular disrupting effects of $\mathrm{CD} 4-\mathrm{TRAIL}^{+}$cells, tumor vasculature was extensively analyzed following in vivo biotinylation for the presence of apoptotic TECs. Consistent with the lack of vascular DR5 expression, TUNEL staining of SU-DHL-4V tumor sections failed to detect apoptotic TECs in CD34-TRAIL ${ }^{+}$ cells-treated tumors, whereas apoptotic TECs could only be detected in mice receiving the combined CD34-TRAIL ${ }^{+}$ cells/perifosine therapy (Fig. 5). Analysis of KMS-11 tumors receiving $\mathrm{CD} 4-\mathrm{TRAIL}^{+}$cells consistently showed apoptotic TECs [40], which were markedly increased by the combined treatment (Fig. 5). As observed in vitro (Fig. 1d), perifosine as single agent was not able to induce apoptosis of TECs in both tumor models (Fig. 5).

Both H\&E staining and TUNEL/glycophorin A doublestaining revealed large areas of hemorrhagic necrosis in tumors showing apoptotic endothelial cells (Figs. 5, 6a), suggesting that apoptosis of TECs is indeed the first event in a complex cascade that finally leads to tumor destruction. Similar to TECs apoptosis, hemorrhagic necrosis in SU-DHL-4V tumors could only be detected after the combined treatment (Fig. 6a). Analysis of KMS-11 tumors showed hemorrhagic necrosis after treatment with both CD34-TRAIL ${ }^{+}$cells alone and in combination with perifosine, with the latter treatment resulting in a significant enhancement of tissue damage (Fig. 6a). An accurate quantification of necrotic areas in whole tumor sections was achieved via a computer-aided analysis with ImageJ software. Treatment of mice bearing SU-DHL-4V tumors with CD34-TRAIL ${ }^{+}$cells alone failed to significantly increase tumor necrosis compared with controls (26.5 \pm 6.7 vs. $16.7 \pm 2.6 \%, P=\mathrm{ns})$, whereas treatment with CD34-TRAIL ${ }^{+}$cells plus perifosine induced a significant increase in tumor necrosis over controls (57.5 \pm 10.0 vs. $16.7 \pm 2.6 \%, P<0.001)$ (Fig. 6b, c). KMS-11 tumors treated with CD34-TRAIL ${ }^{+}$cells plus perifosine showed a twofold increase in tumor necrosis compared to $\mathrm{CD} 4-\mathrm{TRAIL}^{+}$cells alone and a 17-fold increase compared to controls $(31.5 \pm 3.3$ vs. $16.0 \pm 0.8$ vs. $1.8 \pm 0.6 \%, P<0.001$ ) (Fig. $6 \mathrm{~b}, \mathrm{c})$. In keeping with absence of TECs apoptosis in perifosine-treated tumors,
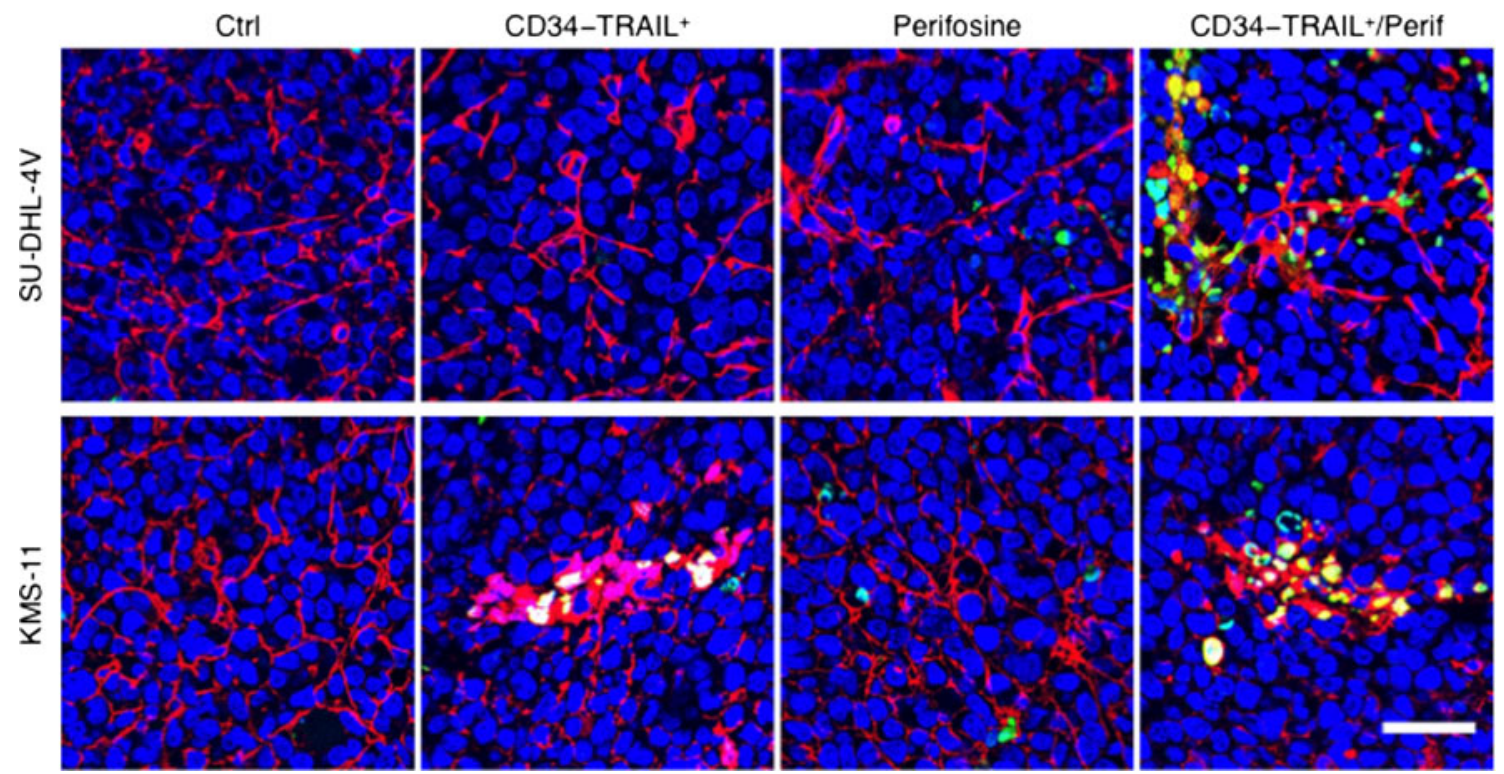

Fig. 5 Perifosine-induced DR5 expression by tumor vasculature sensitizes TECs to CD34-TRAIL ${ }^{+}$cells-induced apoptosis. NOD/ SCID mice bearing subcutaneous tumor nodules were randomly assigned to the different treatment groups consisting of the administration of one injection of CD34-TRAIL ${ }^{+}$cells $\left(3 \times 10^{6}\right.$ cells/ mouse, IV); perifosine at $15 \mathrm{mg} / \mathrm{kg}$ (once daily for 5 days, $\mathrm{PO}$ ); $\mathrm{CD} 4-$ TRAIL $^{+}$cells in combination with perifosine; or vehicle control. Seventy-two hours after treatment with CD34-TRAIL ${ }^{+}$cells and $3 \mathrm{~h}$ after the last perifosine administration, NOD/SCID mice were IV injected with $0.2 \mathrm{ml}$ of sulfo-NHS-LC-biotin $(5 \mathrm{mg} / \mathrm{ml})$ to biotinylate tumor vasculature. Tumors were then excised, fixed in formalin and embedded in paraffin. Representative confocal images of SU-DHL-4V and KMS-11 tumors processed by triple immunofluorescence staining to detect apoptotic tumor endothelial cells are shown. Cell nuclei were detected by blue coloration with TO-PRO-3 staining; apoptotic cells were detected by green coloration with TUNEL staining; and biotinylated tumor endothelial cells were detected by red staining with Alexa 568-conjugated streptavidin. After merging of single color images, endothelial apoptotic nuclei colocalized with sulfo-biotin staining, thus resulting in yellow coloration. Objective lens, original magnification: 1.0 NA oil objective, $\times 40$. Scale bar $50 \mu \mathrm{m}$. (Color figure online) 
perifosine alone failed to induce significant tumor necrosis over controls in either SU-DHL-4V (18.1 \pm 2.5 vs. $16.7 \pm 2.6, P=\mathrm{ns})$ or $\mathrm{KMS}-11(2.6 \pm 0.4$ vs. $1.8 \pm$ $0.6 \%, P=\mathrm{ns}$ ) tumors (Fig. 6b, c).

Apoptosis of TECs resulted also in a marked reduction of tumor vessel density. The combined treatment strongly affected the vascular network of SU-DHL-4V nodules, resulting in a $34 \%$ decrease of vessel density over controls (6 \pm 0.2 vs. $9.1 \pm 0.2 \%, P<0.001)$ (Fig. 7a, b). This finding was paralleled by histological observation of severe disruption of the tumor vasculature, which was deficient in capillaries and lacked most of its branches and sprouts (Fig. 7a). In keeping with the lack of apoptosis in TECs, treatment with $\mathrm{CD}_{34-\mathrm{TRAIL}^{+}}{ }^{+}$cells alone failed to affect SU-DHL-4V tumor vessel density (9.1 \pm 0.2 vs. $8.9 \pm 0.2 \%, P=\mathrm{ns}$ ) and vasculature morphology (Fig. 7a, b). As previously reported [40], CD34-TRAIL ${ }^{+}$cells caused a $34 \%$ decrease of KMS-11 tumors endothelial a

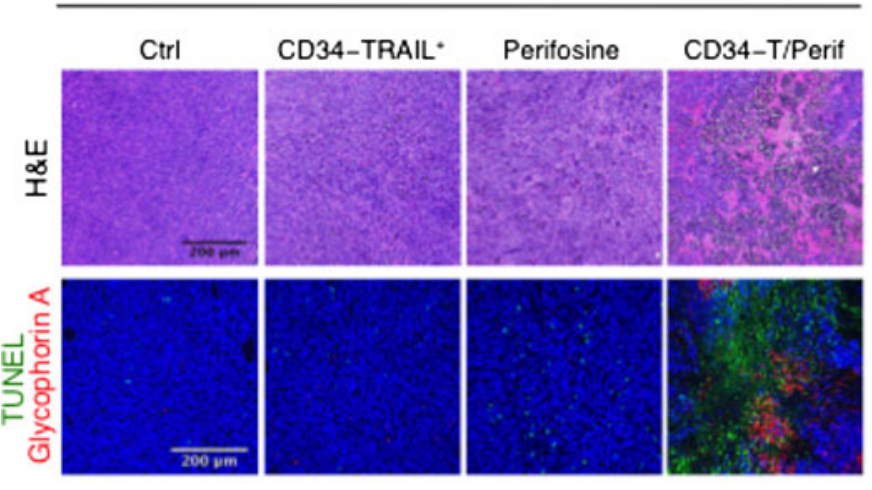

KMS-11

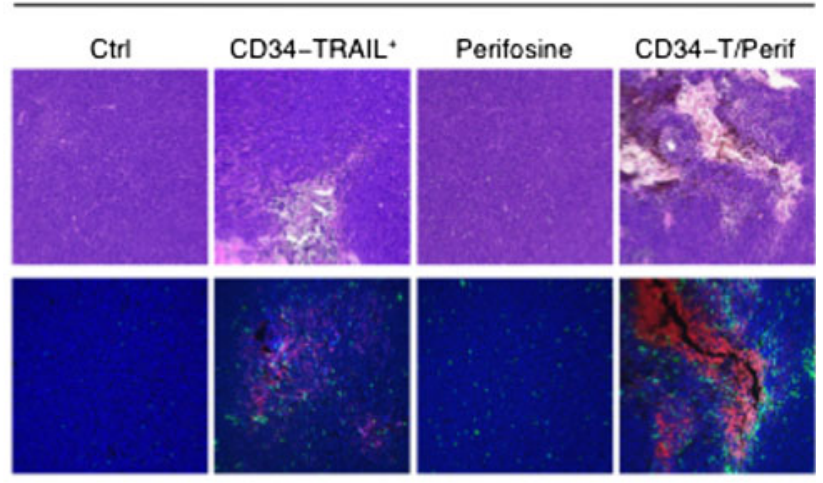

C
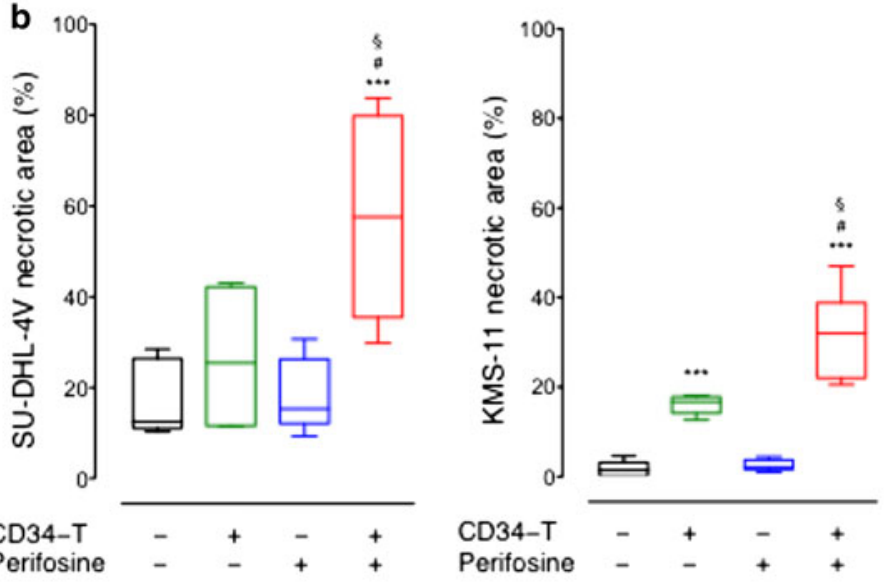

Fig. 6 Apoptosis of TECs causes tumor hemorrhagic necrosis. NOD/ SCID mice bearing subcutaneous tumor nodules were randomly assigned to the different treatment groups consisting of the administration of one injection of CD34-TRAIL ${ }^{+}$cells $\left(3 \times 10^{6}\right.$ cells/ mouse, IV); perifosine at $15 \mathrm{mg} / \mathrm{kg}$ (once daily for 5 days, PO); $\mathrm{CD} 4-\mathrm{TRAIL}^{+}$cells in combination with perifosine; or vehicle control. Seventy-two hours after treatment with CD34-TRAIL ${ }^{+}$cells and $3 \mathrm{~h}$ after the last perifosine administration, tumors were excised, fixed in formalin and embedded in paraffin. a Representative histological and confocal images of SU-DHL-4V and KMS-11 tumors are shown. Tumor tissue morphology was detected by H\&E staining; objective lens, original magnification: 0.40 NA dry objective, $\times 10$; scale bar $200 \mu \mathrm{m}$. Hemorrhagic necrosis was detected by TUNEL/Glycophorin A double immunofluorescence staining: cell death was detected in green by TUNEL staining; red blood cells were detected in red by Glycophorin A staining followed by the appropriate Alexa 568-conjugated secondary antibody; cell nuclei were detected in blue by TO-PRO-3 staining. Objective lens, original magnification: 0.30 NA oil objective, $\times 10$; scale bar $200 \mu \mathrm{m}$. b TUNEL stained SU-DHL-4V and KMS-11 whole tumor sections were digitally acquired and images analyzed using ImageJ for quantification of the percentage of cell death. At least three tumor sections from different animals were analyzed per treatment group. The boxes extend from the 25th to the 75 th percentile; the lines indicate the median values, and the whiskers indicate the range of values. *** $P<0.001$ compared with controls; ${ }^{\#} P<0.001$ compared with CD34-TRAIL ${ }^{+}$cells; ${ }^{\S} P<0.001$ compared with perifosine. c Representative histological images of whole tumor sections from mice receiving the different treatments are shown. Tumor tissue morphology was detected by $\mathrm{H} \& \mathrm{E}$ staining; tumor cell death were detected by TUNEL staining and revealed as brown areas using 3, 3'-diaminobenzidine for light microscopy analysis. Objective lens, original magnification: 0.08 NA dry objective, $\times 2$. (Color figure online) 
density $(6.8 \pm 0.2$ vs. $10.3 \pm 0.2 \%, P<0.001)$ (Fig. 7a, c). The combined treatment drastically enhanced the effects of CD34-TRAIL ${ }^{+}$cells on KMS-11 tumor vasculature, causing an additional $40 \%$ decrease of the endothelial surface, thereby resulting in an overall $60 \%$ reduction of vessel density over controls $(4.1 \pm 0.1$ vs. $6.8 \pm 0.2$ vs. $10.3 \pm 0.2 \%, P<0.001$ ) (Fig. 7a, c). In both tumor models, perifosine alone failed to perturb the vascular network as well as to decrease vessel density (SU-DHL-4V: $9.1 \pm 0.2$ vs. $\quad 9.5 \pm 0.2 \%, \quad P=\mathrm{ns} ; \quad$ KMS-11: $10.3 \pm 0.2$ vs. $10.4 \pm 0.1 \%, P=$ ns) (Fig. 7).

Despite the marked antitumor activity observed in both tumor models, the combined CD34-TRAIL ${ }^{+}$cells/perifosine therapy did not induce any vascular damage or hemorrhagic necrosis in healthy tissues (including lungs, livers, spleens, and femurs), suggesting that perifosine-induced enhancement of the antivascular activity of CD34-
$\mathrm{TRAIL}^{+}$cells was tumor restricted (Online resource 1, Fig. S5).

CD34-TRAIL ${ }^{+}$cells in combination with perifosine strongly slow the growth of subcutaneous tumors

In order to evaluate the effects of the combined treatment on tumor growth, long-term treatment experiments were performed and mice were followed for 2 weeks after the end of the treatments. CD34-TRAIL ${ }^{+}$cells failed to affect the subcutaneous growth of SU-DHL-4V nodules compared to vehicle-treated controls ( $5.7 \pm 0.4$ vs. $6.2 \pm 0.5 \mathrm{~g}, P=\mathrm{ns})$ (Fig. 8). Perifosine used as single agent significantly reduced SU-DHL-4V tumor growth, resulting in an average $42 \%$ reduction of tumor volumes over controls $(3.6 \pm 0.3$ vs. $6.2 \pm 0.5 \mathrm{~g}, P<0.001)$. Notwithstanding the lack of activity of CD34-TRAIL ${ }^{+}$cells when used as a single
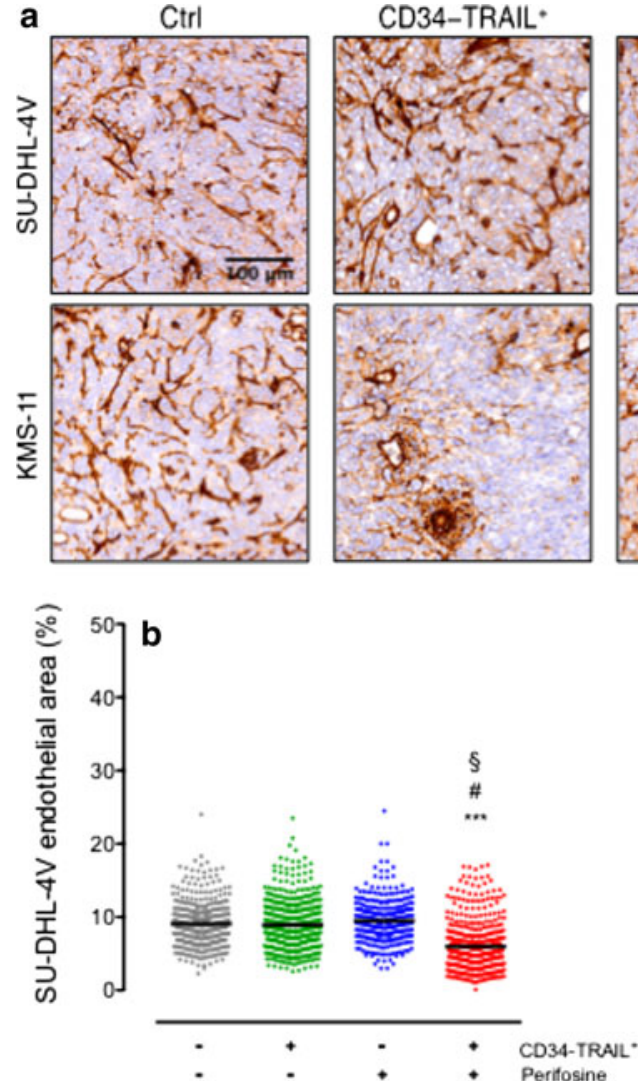

Fig. 7 Enhanced antivascular activity of CD34-TRAIL ${ }^{+}$cells by perifosine markedly reduces tumor vessel density. Seventy-two hours after treatment with $\mathrm{CD} 34-\mathrm{TRAIL}^{+}$cells and $3 \mathrm{~h}$ after the last perifosine administration, NOD/SCID mice were IV injected with $0.2 \mathrm{ml}$ of sulfo-NHS-LC-biotin $(5 \mathrm{mg} / \mathrm{ml})$ to biotinylate the tumor vasculature. Tumors were then excised, embedded in cryoembedding compound and freshly snap-frozen in isopentane. a Representative histological images of tumors from in vivo biotinylated mice receiving the different treatments are shown. Biotinylated endothelia were revealed by sequentially incubating frozen sections with HRP-
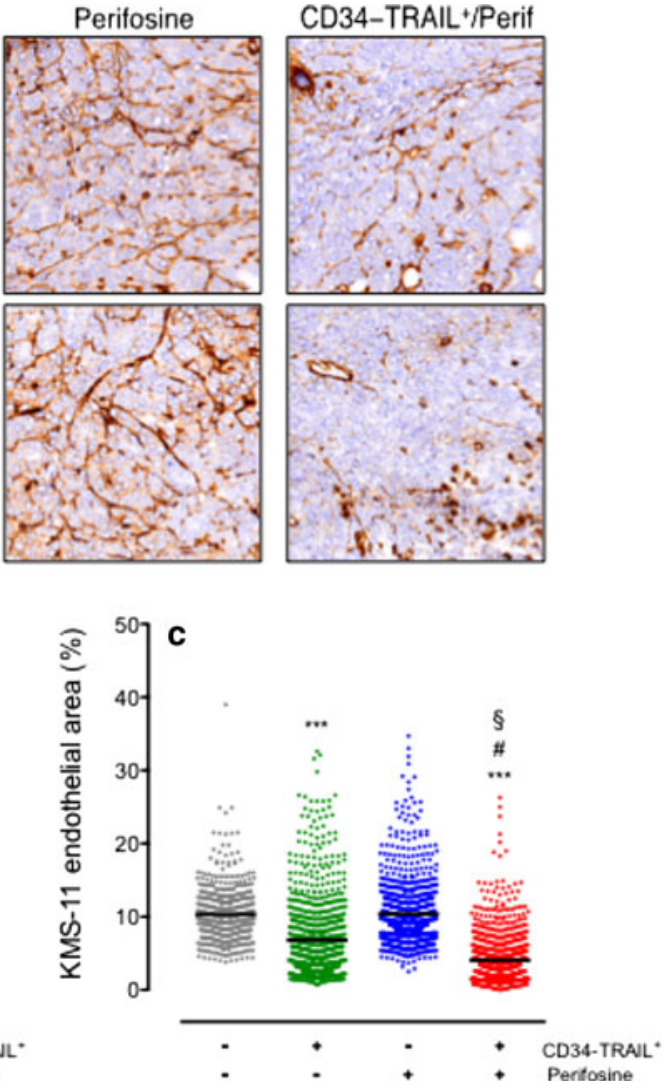

streptavidin and 3,3'-diaminobenzidine for light microscopy analysis. Objective lens, original magnification: 0.75 NA dry objective, $\times 20$; scale bar $100 \mu \mathrm{m}$. b, c HRP-streptavidin stained tumor sections were analyzed using ImageJ for quantification of the endothelial area which was calculated in whole tissue sections as (streptavidin-HRP stained area) $/($ total tissue area) $\times 100$. Each dot represents the value obtained from the analysis of a single tissue field, and the lines indicate the mean values. ${ }^{* * *} P<0.001$ compared with controls; ${ }^{\#} P<0.001$ compared with $\mathrm{CD} 34-\mathrm{TRAIL}^{+}$cells; ${ }^{\S} P<0.001$ compared with perifosine 


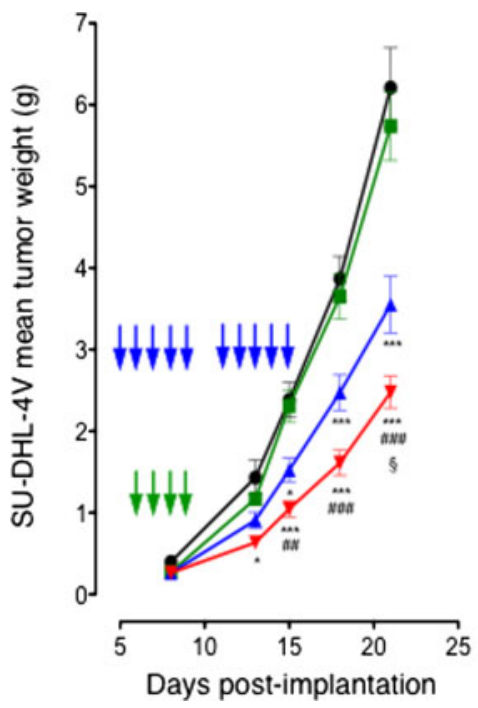

Fig. 8 Effects of CD34-TRAIL ${ }^{+}$cells plus perifosine on tumor growth. NOD/SCID mice bearing subcutaneous tumor nodules were randomly assigned to the different treatment groups consisting of four daily injections of CD34-TRAIL ${ }^{+}$cells (green square $1 \times 10^{6}$ cells/ mouse/day, IV, days 6-9 for SU-DHL-4V and days 12-15 for KMS11); two 5-day courses of perifosine (blue triangle $10 \mathrm{mg} / \mathrm{kg} /$ day, $\mathrm{PO}$, days 5-9 and 11-15 for SU-DHL-4V; $5 \mathrm{mg} / \mathrm{kg}$ per day, PO, days 1 1-15 and 18-22 for KMS-11); treatment with CD34-TRAIL ${ }^{+}$cells in combination with perifosine (red inverted triangle); or treatment

treatment, combined treatment with perifosine reduced the growth of SU-DHL-4V nodules by $60 \%$ compared with controls $(2.5 \pm 0.2$ vs. $6.2 \pm 0.5 \mathrm{~g}, P<0.001)$ and by $31 \%$ over perifosine alone $(2.5 \pm 0.2$ vs. $3.6 \pm 0.3 \mathrm{~g}, P<0.05)$ (Fig. 8). In agreement with previous data [40], the growth of TRAIL-sensitive KMS-11 tumor nodules was significantly inhibited by CD34-TRAIL ${ }^{+}$cells compared to controls, with an average reduction of tumor volumes by $39 \%$ being observed $(P<0.001)$ (Fig. 8). In this tumor model, perifosine reduced tumor volume by $21 \%$ over controls $(P<0.01)$. The combined treatment further reduced tumor volume by $65 \%$ over controls $(2 \pm 0.4$ vs. $5.7 \pm 0.5 \mathrm{~g}$, $P<0.001), 43 \%$ over treatment with CD $34-$ TRAIL $^{+}$cells alone ( $2 \pm 0.4$ vs. $3.5 \pm 0.5 \mathrm{~g}, P<0.001)$, and $56 \%$ over perifosine alone $(2 \pm 0.4$ vs. $4.5 \pm 0.6 \mathrm{~g}, P<0.001)$ (Fig. 8).

Whereas perifosine as a single agent was ineffective to induce endothelial apoptosis and vascular disruption (see Figs. 5, 7), it caused a significant growth delay of both tumor models. Perifosine has been reported to induce apoptosis in several tumor cell lines, such as human lung cancer cells [13], human multiple myeloma cells [15, 47], acute myelogenous leukemia cells [48] and Hodgkin Lymphoma cells [49]. As regard to tumor cell lines used in this work, perifosine significantly increased tumor cell death both in vitro and in vivo (Online resource 1, Fig. S6), that might explain the tumor growth delay observed in vivo following perifosine treatment.

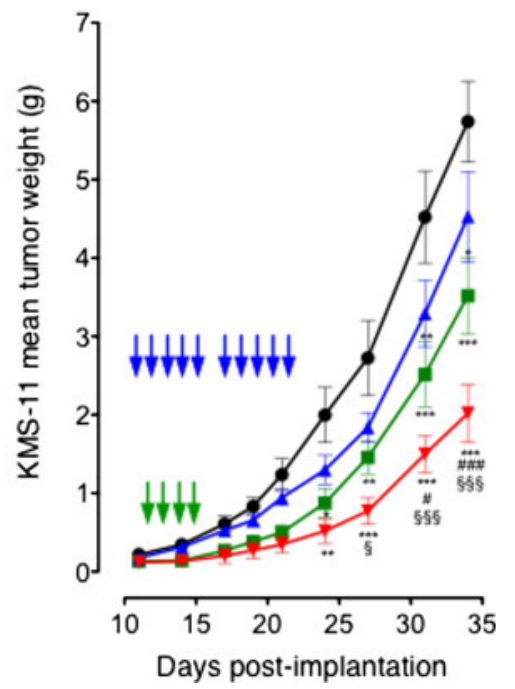

with vehicle control (black circle). Green arrows indicate CD34$\mathrm{TRAIL}^{+}$cells administration; blue arrows indicate perifosine administration. Mean \pm SEM tumor weight data are shown $(n=15$ per group). $* P<0.05$ compared with controls, $* * P<0.01$ compared with controls, ***P $<0.001$ compared with controls; ${ }^{\#} P<0.05$ compared with CD34-TRAIL ${ }^{+}$cells, ${ }^{\# \#} P<0.01$ compared with CD34-TRAIL ${ }^{+}$cells, ${ }^{\# \# \#} P<0.001$ compared with CD34-TRAIL ${ }^{+}$ cells; ${ }^{\S} P<0.05$ compared with perifosine, ${ }^{\S \S \S} P<0.001$ compared with perifosine. (Color figure online)

\section{Discussion}

In agreement with our previous data [40], Wilson et al. [41] have recently demonstrated that vascular disruption activity of a cross-linked version of Apo2L/TRAIL, that mimics the transmembrane ligand, requires DR5 expression on tumor endothelial cells. Our in vitro studies and the tumor model SU-DHL-4V used in this work confirm that DR5 expression on TEC is needed for CD34-TRAIL ${ }^{+}$cells performing antivascular activity and that lack of DR5 vascular expression represents a mechanism of resistance to mTRAIL-expressing $\mathrm{CD} 34^{+}$cells.

Thus, modulating DR5 on TECs might not only enhance CD34-TRAIL ${ }^{+}$cells antitumor efficacy but also eventually restore the antivascular activity of CD34TRAIL $^{+}$cells as well as other membrane-bound or crosslinked forms of TRAIL in tumors lacking endothelial DR5.

Data reported herein clearly demonstrate for the first time that (1) perifosine induces DR5 expression in tumor vasculature, and (2) perifosine-mediated modulation of DR5 expression on TECs can overcome resistance to the vascular disrupting effects of membrane-bound TRAIL. In fact, the combined CD34-TRAIL ${ }^{+}$cells/perifosine treatment induced a number of objectively quantifiable antivascular and antitumor effects in vascular DR5-lacking SU-DHL-4V tumors, which were specifically observed only using the combined treatment. 
It has been established that the JNK/c-Jun axis could positively regulate DR5 transcription [50]. A functional activator protein-1 (AP-1) binding site has been shown in the promoter region of DR5. JNK, by increasing c-Jun phosphorylation, leads to an increase in AP-1 activity [51]. Interestingly, Akt appears to negatively regulate JNK signaling by directly interacting with the JNK activators Mixed Lineage Kinase 3 (MLK3) and Apoptosis Signalregulating Kinase 1 (ASK1), thus causing their inhibition [52, 53]. Several in vitro studies have investigated the mechanism(s) by which perifosine modulates TRAIL receptors expression on tumor cells. Tazzari et al. [17] suggested that perifosine induces JNK-dependent DR5 overexpression in leukemia cells. Fu et al. [18] have recently reported that perifosine increases the levels of p-JNK and p-c-Jun in head and neck squamous cell carcinomas and that activation of JNK signaling parallels the upregulation of DR4 and DR5. However studies investigating these effects in tumor endothelial cells are steel lacking. Here we show that in vivo administration of perifosine strongly inhibits tumor endothelial Akt phosphorylation and upregulates (see KMS-11 tumor model) or even induces de novo expression (see SU-DHL-4V tumor model) of DR5 in TECs in a JNK-dependent manner. In fact, perifosine increased phosphorylation of JNK and c-Jun in tumor endothelial cells both in vitro and in vivo and inhibition of JNK by the specific inhibitor SP600125 prevented DR5 perifosine-induced upregulation, supporting the hypothesis perifosine might upmodulate DR5 levels in TECs via JNK activation.

Interesting is to note as the phenotype of tumor endothelial cells, which derived from the same host normal endothelium, was tightly dependent on tumor type. Indeed, TECs from SU-DHL-4V tumors did not express DR5 on their surface, whereas about $40 \%$ of TECs from KMS-11 tumors expressed the receptor. This evidence suggests that different tumor cells can even modulate tumor microenvironment influencing therapeutic outcome [54]. It will be interesting to determine what specific features of the tumor microenvironment drive endothelial DR5 expression.

Akt activation plays an important role in regulating the survival and proliferation of both tumor cells and TECs. Although Akt phosphorylation in tumor cells as well as tumor vasculature was strongly inhibited by perifosine, analysis of the tumor vasculature of our xenografts clearly showed that perifosine as a single agent was ineffective to induce endothelial cell apoptosis and vascular disruption or to inhibit tumor angiogenesis, whereas it caused tumor cell apoptosis and a significant growth delay of both tumor models. In 2008 Zerp et al. [55] studied the antiangiogenic properties of the alkylphospholopids (APLs) perifosine, miltefosine and edelfosine in vitro. They demonstrated that APLs inhibit capillary-like endothelial tube formation and that the sensitivity of normal vascular endothelial cells (ECs) to APL-induced apoptosis is dependent on the proliferative status of these cells: confluent, quiescent ECs were relatively resistant, whereas proliferating ECs were highly sensitive to APL-induced apoptosis. In agreement with these data, we observed in vitro induction of apoptosis in HUVEC proliferating cells treated with $5 \mu \mathrm{M}$ perifosine (data not shown), but no apoptosis was observed in perifosine-treated tumorderived $2 \mathrm{H}-11$ endothelial cells. It is widely appreciated that tumor-associated endothelial cells have a unique activated phenotype and a different structure compared to those in normal quiescent tissues beacause of the exposure to a distinct set of stimuli in their local environment [56]. Furthermore, although tumor-associated angiogenesis has traditionally been defined as the sprouting of new vessels from preexisting vessels, it is becoming clear that the blood vessels that support tumor growth can also originate from cells recruited from the bone marrow or can even differentiate from tumor stem cells (vascular mimicry) [57, 58]. All toghether these factors can determine different responses in normal cultured endothelial cells and tumor-associated endothelial cells exposed to the same drug.

As mentioned above, although perifosine as a single agent was ineffective to induce endothelial cells apoptosis, it sensitized TECs to CD34-TRAIL ${ }^{+}$cells-induced vascular disruption by upmodulating DR5 expression and caused tumor cell apoptosis. In addition to targeting Akt and modulating JNK activation and DR5 expression, perifosine possesses other biologic activities (reviewed in [59]) that may contribute to the effects observed in this work. These include, accumulation into lipid rafts of the plasma membrane [60] and downregulation of ERK 1/2 phosphorylation [48]. Analysis of tumor xenografts revealed a strong reduction in ERK phosphorylation levels following perifosine treatment (data not shown), indicating that inhibition of MAPK signaling by perifosine toghether with Akt inhibition might also be involved in inducing tumor cells apoptosis and tumor growth delay. In 2007 van der Luit et al. [60] reported perifosine incorporation into lipid rafts followed by inhibition of phosphatidylcholine synthesis and induction of apoptosis in lymphoma cells; in the same year Gajate and Mollinedo [61] demonstrated that perifosine induces apoptosis in multiple myeloma (MM) by recruitment of death receptors into lipid rafts and observed that the concentration of death receptors in lipid rafts following perifosine treatment rendered MM cells more sensitive to the action of death receptor ligands, such as TRAIL. Considering these previous observations, we can not exclude that perifosine sensitized TECs to CD34TRAIL $^{+}$cells-induced apoptosis not only by upregulating DR5 expression but also by acting on plasma membrane reorganization and causing DR5 accumulation into lipid rafts. 
A major concern associated with the use of vascular disrupting agents in the treatment of cancer is the possibility of undesirable organ toxicities due to damaging healthy tissue vasculature. We have previously demonstrated that repeated injections of CD34-TRAIL ${ }^{+}$cells used as a single agent fail to induce normal endothelial cell toxicity [40]. Data reported herein clearly show that perifosine-mediated enhancement of the antivascular activity of CD34-TRAIL ${ }^{+}$cells is tumor-restricted not involving normal endothelial cells. In fact, histological analysis of healthy organs, including lungs, livers, spleens and femurs, failed to reveal any vascular damage or necrotic events following treatment with CD34TRAIL $^{+}$cells plus perifosine. This finding rules out any concern regarding the systemic toxicity of the combined CD34-TRAIL $^{+}$cells/perifosine treatment in the clinical setting. Furthermore, confocal microscopy analysis actually revealed intense tumor-restricted expression of phosphorylated Akt in tumor cells as well as tumor vasculature, while no Akt activation could be observed when parenchyma or endothelial cells from healthy organs were extensively analyzed, in agreement with data reported by others [62-64].

To the best of our knowledge, the work reported herein represents the first demonstration of the capacity of perifosine to upregulate in vivo DR5 expression in tumor vasculature. These findings are relevant in view of future clinical studies using membrane-bound TRAIL since perifosine might be used to rescue patients with primary or acquired resistance due to the lack of DR5 expression in tumor vasculature.

Acknowledgments We are indebted to Prof. Marco Presta (Department of Molecular and Translational Medicine, University of Brescia, Brescia, Italy) for continuous support and critical revision of the manuscript. This work was supported in part by grants from the Ministry of Education, University and Research (Rome, Italy), the Ministry of Health (Ricerca Finalizzata 2010 to C.C.-S.), and the Italian Association for Cancer Research (MCO - 9998 to C.C.-S. and A.M.G.).

Conflict of interest The authors declare no competing financial interests.

Ethical standards Animal experiments were performed according to the Italian laws (D.L. 116/92 and following additions) that enforce the EU 86/109 Directive and were approved by the institutional Ethical Committee for Animal Experimentation.

\section{References}

1. Altomare DA, Testa JR (2005) Perturbations of the AKT signaling pathway in human cancer. Oncogene 24(50):7455-7464. doi:10.1038/sj.onc.1209085

2. Kim D, Dan HC, Park S, Yang L, Liu Q, Kaneko S, Ning J, He L, Yang H, Sun M, Nicosia SV, Cheng JQ (2005) AKT/PKB signaling mechanisms in cancer and chemoresistance. Front Biosci 10:975-987

3. Jiang BH, Liu LZ (2008) PI3K/PTEN signaling in tumorigenesis and angiogenesis. Biochim Biophys Acta 1784(1):150-158. doi: 10.1016/j.bbapap.2007.09.008

4. Tokunaga E, Oki E, Egashira A, Sadanaga N, Morita M, Kakeji Y, Maehara Y (2008) Deregulation of the Akt pathway in human cancer. Curr Cancer Drug Targets 8(1):27-36

5. Cantley LC (2002) The phosphoinositide 3-kinase pathway. Science 296(5573):1655-1657. doi:10.1126/science.296.5573. $1655296 / 5573 / 1655$

6. LoPiccolo J, Blumenthal GM, Bernstein WB, Dennis PA (2008) Targeting the PI3K/Akt/mTOR pathway: effective combinations and clinical considerations. Drug Resist Updat 11(1-2):32-50. doi:10.1016/j.drup.2007.11.003

7. Van Ummersen L, Binger K, Volkman J, Marnocha R, Tutsch K, Kolesar J, Arzoomanian R, Alberti D, Wilding G (2004) A phase I trial of perifosine (NSC 639966) on a loading dose/maintenance dose schedule in patients with advanced cancer. Clin Cancer Res 10(22):7450-7456. doi:10.1158/1078-0432.CCR-03-0406

8. Posadas EM, Gulley J, Arlen PM, Trout A, Parnes HL, Wright J, Lee MJ, Chung EJ, Trepel JB, Sparreboom A, Chen C, Jones E, Steinberg SM, Daniels A, Figg WD, Dahut WL (2005) A phase II study of perifosine in androgen independent prostate cancer. Cancer Biol Ther 4(10):1133-1137

9. Bailey HH, Mahoney MR, Ettinger DS, Maples WJ, Fracasso PM, Traynor AM, Erlichman C, Okuno SH (2006) Phase II study of daily oral perifosine in patients with advanced soft tissue sarcoma. Cancer 107(10):2462-2467. doi:10.1002/cncr.22308

10. Leighl NB, Dent S, Clemons M, Vandenberg TA, Tozer R, Warr DG, Crump RM, Hedley D, Pond GR, Dancey JE, Moore MJ (2008) A Phase 2 study of perifosine in advanced or metastatic breast cancer. Breast Cancer Res Treat 108(1):87-92. doi: 10.1007/s10549-007-9584-x

11. Crul M, Rosing H, de Klerk GJ, Dubbelman R, Traiser M, Reichert S, Knebel NG, Schellens JH, Beijnen JH, ten Bokkel Huinink WW (2002) Phase I and pharmacological study of daily oral administration of perifosine (D-21266) in patients with advanced solid tumours. Eur J Cancer 38(12):1615-1621

12. Kondapaka SB, Singh SS, Dasmahapatra GP, Sausville EA, Roy KK (2003) Perifosine, a novel alkylphospholipid, inhibits protein kinase B activation. Mol Cancer Ther 2(11):1093-1103

13. Elrod HA, Lin YD, Yue P, Wang X, Lonial S, Khuri FR, Sun SY (2007) The alkylphospholipid perifosine induces apoptosis of human lung cancer cells requiring inhibition of Akt and activation of the extrinsic apoptotic pathway. Mol Cancer Ther 6(7):2029-2038. doi:10.1158/1535-7163.MCT-07-0004

14. Hennessy BT, Lu Y, Poradosu E, Yu Q, Yu S, Hall H, Carey MS, Ravoori M, Gonzalez-Angulo AM, Birch R, Henderson IC, Kundra V, Mills GB (2007) Pharmacodynamic markers of perifosine efficacy. Clin Cancer Res 13(24):7421-7431. doi:10. 1158/1078-0432.CCR-07-0760

15. Hideshima T, Catley L, Yasui H, Ishitsuka K, Raje N, Mitsiades C, Podar K, Munshi NC, Chauhan D, Richardson PG, Anderson KC (2006) Perifosine, an oral bioactive novel alkylphospholipid, inhibits Akt and induces in vitro and in vivo cytotoxicity in human multiple myeloma cells. Blood 107(10):4053-4062. doi: 10.1182/blood-2005-08-3434

16. David E, Sinha R, Chen J, Sun SY, Kaufman JL, Lonial S (2008) Perifosine synergistically enhances TRAIL-induced myeloma cell apoptosis via up-regulation of death receptors. Clin Cancer Res 14(16):5090-5098. doi:10.1158/1078-0432.CCR-08-0016

17. Tazzari PL, Tabellini G, Ricci F, Papa V, Bortul R, Chiarini F, Evangelisti C, Martinelli G, Bontadini A, Cocco L, McCubrey JA, Martelli AM (2008) Synergistic proapoptotic activity of recombinant TRAIL plus the Akt inhibitor Perifosine in acute 
myelogenous leukemia cells. Cancer Res 68(22):9394-9403. doi: 10.1158/0008-5472.CAN-08-2815

18. Fu L, Lin YD, Elrod HA, Yue P, Oh Y, Li B, Tao H, Chen GZ, Shin DM, Khuri FR, Sun SY (2010) c-Jun NH2-terminal kinasedependent upregulation of DR5 mediates cooperative induction of apoptosis by perifosine and TRAIL. Mol Cancer 9:315. doi: 10.1186/1476-4598-9-315

19. Rieger J, Naumann U, Glaser T, Ashkenazi A, Weller M (1998) APO2 ligand: a novel lethal weapon against malignant glioma? FEBS Lett 427(1):124-128

20. Ashkenazi A, Pai RC, Fong S, Leung S, Lawrence DA, Marsters SA, Blackie C, Chang L, McMurtrey AE, Hebert A, DeForge L, Koumenis IL, Lewis D, Harris L, Bussiere J, Koeppen H, Shahrokh Z, Schwall RH (1999) Safety and antitumor activity of recombinant soluble Apo2 ligand. J Clin Invest 104(2):155-162. doi:10.1172/JCI6926

21. Gazitt Y (1999) TRAIL is a potent inducer of apoptosis in myeloma cells derived from multiple myeloma patients and is not cytotoxic to hematopoietic stem cells. Leukemia 13(11): 1817-1824

22. Kelley SK, Harris LA, Xie D, Deforge L, Totpal K, Bussiere J, Fox JA (2001) Preclinical studies to predict the disposition of Apo2L/tumor necrosis factor-related apoptosis-inducing ligand in humans: characterization of in vivo efficacy, pharmacokinetics, and safety. J Pharmacol Exp Ther 299(1):31-38

23. Mitsiades CS, Treon SP, Mitsiades N, Shima Y, Richardson P, Schlossman R, Hideshima T, Anderson KC (2001) TRAIL/ Apo2L ligand selectively induces apoptosis and overcomes drug resistance in multiple myeloma: therapeutic applications. Blood 98(3):795-804

24. Pollack IF, Erff M, Ashkenazi A (2001) Direct stimulation of apoptotic signaling by soluble Apo2 1/tumor necrosis factorrelated apoptosis-inducing ligand leads to selective killing of glioma cells. Clin Cancer Res 7(5):1362-1369

25. Almasan A, Ashkenazi A (2003) Apo2L/TRAIL: apoptosis signaling, biology, and potential for cancer therapy. Cytokine Growth Factor Rev 14(3-4):337-348

26. Jin H, Yang R, Fong S, Totpal K, Lawrence D, Zheng Z, Ross J, Koeppen H, Schwall R, Ashkenazi A (2004) Apo2 ligand/tumor necrosis factor-related apoptosis-inducing ligand cooperates with chemotherapy to inhibit orthotopic lung tumor growth and improve survival. Cancer Res 64(14):4900-4905. doi: 10.1158/0008-5472.CAN-04-040864/14/4900

27. Daniel D, Yang B, Lawrence DA, Totpal K, Balter I, Lee WP, Gogineni A, Cole MJ, Yee SF, Ross S, Ashkenazi A (2007) Cooperation of the proapoptotic receptor agonist rhApo2L/ TRAIL with the CD20 antibody rituximab against non-Hodgkin lymphoma xenografts. Blood 110(12):4037-4046. doi:10.1182/ blood-2007-02-076075

28. Koschny R, Walczak H, Ganten TM (2007) The promise of TRAIL-potential and risks of a novel anticancer therapy. J Mol Med 85(9):923-935. doi:10.1007/s00109-007-0194-1

29. Ashkenazi A, Holland P, Eckhardt SG (2008) Ligand-based targeting of apoptosis in cancer: the potential of recombinant human apoptosis ligand 2/tumor necrosis factor-related apoptosisinducing ligand (rhApo2L/TRAIL). J Clin Oncol 26(21):36213630. doi:10.1200/JCO.2007.15.7198

30. Duiker EW, Mom CH, de Jong S, Willemse PH, Gietema JA, van der Zee AG, de Vries EG (2006) The clinical trail of TRAIL. Eur J Cancer 42(14):2233-2240. doi:10.1016/j.ejca.2006.03.018

31. Bellail AC, Qi L, Mulligan P, Chhabra V, Hao C (2009) TRAIL agonists on clinical trials for cancer therapy: the promises and the challenges. Rev Recent Clin Trials 4(1):34-41

32. Herbst RS, Eckhardt SG, Kurzrock R, Ebbinghaus S, O'Dwyer PJ, Gordon MS, Novotny W, Goldwasser MA, Tohnya TM, Lum BL, Ashkenazi A, Jubb AM, Mendelson DS (2010) Phase I dose- escalation study of recombinant human Apo2L/TRAIL, a dual proapoptotic receptor agonist, in patients with advanced cancer. J Clin Oncol 28(17):2839-2846. doi:10.1200/JCO.2009.25.1991

33. Tolcher AW, Mita M, Meropol NJ, von Mehren M, Patnaik A, Padavic K, Hill M, Mays T, McCoy T, Fox NL, Halpern W, Corey A, Cohen RB (2007) Phase I pharmacokinetic and biologic correlative study of mapatumumab, a fully human monoclonal antibody with agonist activity to tumor necrosis factor-related apoptosis-inducing ligand receptor-1. J Clin Oncol 25(11):1390 1395. doi:10.1200/JCO.2006.08.8898

34. Leong S, Cohen RB, Gustafson DL, Langer CJ, Camidge DR, Padavic K, Gore L, Smith M, Chow LQ, von Mehren M, O'Bryant C, Hariharan S, Diab S, Fox NL, Miceli R, Eckhardt SG (2009) Mapatumumab, an antibody targeting TRAIL-R1, in combination with paclitaxel and carboplatin in patients with advanced solid malignancies: results of a phase I and pharmacokinetic study. J Clin Oncol 27(26):4413-4421. doi:10.1200/ JCO.2008.21.7422

35. Trarbach T, Moehler M, Heinemann V, Kohne CH, Przyborek M, Schulz C, Sneller V, Gallant G, Kanzler S (2010) Phase II trial of mapatumumab, a fully human agonistic monoclonal antibody that targets and activates the tumour necrosis factor apoptosisinducing ligand receptor-1 (TRAIL-R1), in patients with refractory colorectal cancer. Br J Cancer 102(3):506-512. doi:10. 1038/sj.bjc.6605507

36. Wakelee HA, Patnaik A, Sikic BI, Mita M, Fox NL, Miceli R, Ullrich SJ, Fisher GA, Tolcher AW (2010) Phase I and pharmacokinetic study of lexatumumab (HGS-ETR2) given every 2 weeks in patients with advanced solid tumors. Ann Oncol 21(2):376-381. doi:10.1093/annonc/mdp292

37. Younes A, Vose JM, Zelenetz AD, Smith MR, Burris HA, Ansell SM, Klein J, Halpern W, Miceli R, Kumm E, Fox NL, Czuczman MS (2010) A Phase 1b/2 trial of mapatumumab in patients with relapsed/refractory non-Hodgkin's lymphoma. Br J Cancer 103 (12):1783-1787. doi:10.1038/sj.bjc.6605987

38. Wiezorek J, Holland P, Graves J (2010) Death receptor agonists as a targeted therapy for cancer. Clin Cancer Res 16(6):17011708. doi:10.1158/1078-0432.CCR-09-1692

39. Carlo-Stella C, Lavazza C, Di Nicola M, Cleris L, Longoni P, Milanesi M, Magni M, Morelli D, Gloghini A, Carbone A, Gianni AM (2006) Antitumor activity of human CD $34^{+}$cells expressing membrane-bound tumor necrosis factor-related apoptosis-inducing ligand. Hum Gene Ther 17(12):1225-1240. doi:10.1089/hum. 2006.17.1225

40. Lavazza C, Carlo-Stella C, Giacomini A, Cleris L, Righi M, Sia D, Di Nicola M, Magni M, Longoni P, Milanesi M, Francolini M, Gloghini A, Carbone A, Formelli F, Gianni AM (2010) Human $\mathrm{CD}^{+} 4^{+}$cells engineered to express membrane-bound tumor necrosis factor-related apoptosis-inducing ligand target both tumor cells and tumor vasculature. Blood 115(11):2231-2240. doi:10.1182/blood-2009-08-239632

41. Wilson NS, Yang A, Yang B, Couto S, Stern H, Gogineni A, Pitti R, Marsters S, Weimer RM, Singh M, Ashkenazi A (2012) Proapoptotic activation of death receptor 5 on tumor endothelial cells disrupts the vasculature and reduces tumor growth. Cancer Cell 22(1):80-90. doi:10.1016/j.ccr.2012.05.014

42. Ronchetti D, Greco A, Compasso S, Colombo G, Dell'Era P, Otsuki T, Lombardi L, Neri A (2001) Deregulated FGFR3 mutants in multiple myeloma cell lines with $\mathrm{t}(4 ; 14)$ : comparative analysis of Y373C, K650E and the novel G384D mutations. Oncogene 20(27):3553-3562. doi:10.1038/sj.onc.1204465

43. Lavazza C, Carlo-Stella C, Di Nicola M, Longoni P, Milanesi M, Magni M, Gianni AM (2007) Highly efficient gene transfer into mobilized CD34 ${ }^{+}$hematopoietic cells using serotype-5 adenoviral vectors and BoosterExpress Reagent. Exp Hematol 35(6):888-897. doi:10.1016/j.exphem.2007.02.010 
44. O'Connell KA, Rudmann AA (1993) Cloned spindle and epithelioid cells from murine Kaposi's sarcoma-like tumors are of endothelial origin. J Invest Dermatol 100(6):742-745

45. Bardin N, Anfosso F, Masse JM, Cramer E, Sabatier F, Le Bivic A, Sampol J, Dignat-George F (2001) Identification of CD146 as a component of the endothelial junction involved in the control of cell-cell cohesion. Blood 98(13):3677-3684

46. Schrage A, Loddenkemper C, Erben U, Lauer U, Hausdorf G, Jungblut PR, Johnson J, Knolle PA, Zeitz M, Hamann A, Klugewitz K (2008) Murine CD146 is widely expressed on endothelial cells and is recognized by the monoclonal antibody ME-9F1. Histochem Cell Biol 129(4):441-451. doi: 10.1007/s00418-008-0379-x

47. Catley L, Hideshima T, Chauhan D, Neri P, Tassone P, Bronson R, Song W, Tai YT, Munshi NC, Anderson KC (2007) Alkyl phospholipid perifosine induces myeloid hyperplasia in a murine myeloma model. Exp Hematol 35(7):1038-1046. doi: 10.1016/j.exphem.2007.03.020

48. Papa V, Tazzari PL, Chiarini F, Cappellini A, Ricci F, Billi AM, Evangelisti C, Ottaviani E, Martinelli G, Testoni N, McCubrey JA, Martelli AM (2008) Proapoptotic activity and chemosensitizing effect of the novel Akt inhibitor perifosine in acute myelogenous leukemia cells. Leukemia 22(1):147-160. doi: 10.1038/sj.leu.2404980

49. Locatelli SL, Giacomini A, Guidetti A, Cleris L, Mortarini R, Anichini A, Gianni AM, Carlo-Stella C (2013) Perifosine and sorafenib combination induces mitochondrial cell death and antitumor effects in NOD/SCID mice with Hodgkin lymphoma cell line xenografts. Leukemia. doi:10.1038/leu.2013.28

50. Zou W, Liu X, Yue P, Zhou Z, Sporn MB, Lotan R, Khuri FR, Sun SY (2004) c-Jun NH2-terminal kinase-mediated up-regulation of death receptor 5 contributes to induction of apoptosis by the novel synthetic triterpenoid methyl-2-cyano-3,12-dioxooleana-1, 9-dien-28-oate in human lung cancer cells. Cancer Res 64(20):7570-7578. doi:10.1158/0008-5472.CAN-04-1238

51. Verde P, Casalino L, Talotta F, Yaniv M, Weitzman JB (2007) Deciphering AP-1 function in tumorigenesis: fra-ternizing on target promoters. Cell Cycle 6(21):2633-2639

52. Barthwal MK, Sathyanarayana P, Kundu CN, Rana B, Pradeep A, Sharma C, Woodgett JR, Rana A (2003) Negative regulation of mixed lineage kinase 3 by protein kinase B/AKT leads to cell survival. J Biol Chem 278(6):3897-3902. doi:10.1074/jbc.M211 598200

53. Kim AH, Khursigara G, Sun X, Franke TF, Chao MV (2001) Akt phosphorylates and negatively regulates apoptosis signal-regulating kinase 1. Mol Cell Biol 21(3):893-901. doi:10.1128/ MCB.21.3.893-901.2001

54. Khodarev NN, Yu J, Labay E, Darga T, Brown CK, Mauceri HJ, Yassari R, Gupta N, Weichselbaum RR (2003) Tumour- endothelium interactions in co-culture: coordinated changes of gene expression profiles and phenotypic properties of endothelial cells. J Cell Sci 116(Pt 6):1013-1022

55. Zerp SF, Vink SR, Ruiter GA, Koolwijk P, Peters E, van der Luit AH, de Jong D, Budde M, Bartelink H, van Blitterswijk WJ, Verheij M (2008) Alkylphospholipids inhibit capillary-like endothelial tube formation in vitro: antiangiogenic properties of a new class of antitumor agents. Anticancer Drugs 19(1):65-75. doi:10.1097/ CAD.0b013e3282f16d3600001813-200801000-00008

56. Baluk P, Hashizume H, McDonald DM (2005) Cellular abnormalities of blood vessels as targets in cancer. Curr Opin Genet Dev 15(1):102-111. doi:10.1016/j.gde.2004.12.005

57. Bussolati B, Grange C, Camussi G (2011) Tumor exploits alternative strategies to achieve vascularization. FASEB J 25(9):2874-2882. doi:10.1096/fj.10-180323

58. Lyden D, Hattori K, Dias S, Costa C, Blaikie P, Butros L, Chadburn A, Heissig B, Marks W, Witte L, Wu Y, Hicklin D, Zhu Z, Hackett NR, Crystal RG, Moore MA, Hajjar KA, Manova K, Benezra R, Rafii S (2001) Impaired recruitment of bonemarrow-derived endothelial and hematopoietic precursor cells blocks tumor angiogenesis and growth. Nat Med 7(11):11941201. doi:10.1038/nm1101-1194

59. van Blitterswijk WJ, Verheij M (2008) Anticancer alkylphospholipids: mechanisms of action, cellular sensitivity and resistance, and clinical prospects. Curr Pharm Des 14(21):2061-2074

60. van der Luit AH, Vink SR, Klarenbeek JB, Perrissoud D, Solary E, Verheij M, van Blitterswijk WJ (2007) A new class of anticancer alkylphospholipids uses lipid rafts as membrane gateways to induce apoptosis in lymphoma cells. Mol Cancer Ther 6(8):2337-2345. doi:10.1158/1535-7163.MCT-07-0202

61. Gajate C, Mollinedo F (2007) Edelfosine and perifosine induce selective apoptosis in multiple myeloma by recruitment of death receptors and downstream signaling molecules into lipid rafts. Blood 109(2):711-719. doi:10.1182/blood-2006-04-016824

62. Bussolati B, Deambrosis I, Russo S, Deregibus MC, Camussi G (2003) Altered angiogenesis and survival in human tumorderived endothelial cells. FASEB J 17(9):1159-1161. doi: 10.1096/fj.02-0557fje02-0557fje

63. Sun JF, Phung T, Shiojima I, Felske T, Upalakalin JN, Feng D, Kornaga T, Dor T, Dvorak AM, Walsh K, Benjamin LE (2005) Microvascular patterning is controlled by fine-tuning the Akt signal. Proc Natl Acad Sci USA 102(1):128-133. doi:10.1073/ pnas.0403198102

64. Bussolati B, Assenzio B, Deregibus MC, Camussi G (2006) The proangiogenic phenotype of human tumor-derived endothelial cells depends on thrombospondin-1 downregulation via phosphatidylinositol 3-kinase/Akt pathway. J Mol Med (Berl) 84(10):852-863. doi:10.1007/s00109-006-0075-Z 